\title{
Geological Characteristics of Shallow Groundwater Aquifer and its Relation to Hydrochemical Features and Bacteriological Pollutants in Siwa Oasis, Egypt
}

\author{
Amr M. Abdel-Gawad ${ }^{1}$, El Sayed A. El Abd ${ }^{2}$ and Yahia R. Gedamy ${ }^{3}$
}

\author{
${ }^{1}$ Soil Fertility and Microbiology Department, Desert Research Center, Cairo, Egypt. \\ ${ }^{2}$ Geology Department, Desert Research Center, Cairo, Egypt. \\ ${ }^{3}$ Hydrogeochemistry Department, Desert Research Center, Cairo, Egypt.
}

Received: 25 Mar. 2020 / Accepted 07 May 2020 / Publication date: 20 May 2020

\begin{abstract}
This study aims to delineate the geological characteristics of the shallow groundwater aquifer and assess its relation to the hydrochemical features and bacteriological pollutants to understand the nature and degree of occurrence of contamination in Siwa Oasis, Egypt. To achieve this aim, thirty seven water samples (lakes, drains and springs water samples as well as Miocene and Nubian sandstone groundwater samples) were collected from the study area and analyzed for several parameters in order to determine the major constituents $\left(\mathrm{Ca}^{2+}, \mathrm{Mg}^{2+}, \mathrm{Na}^{+}, \mathrm{K}^{+}, \mathrm{CO}_{3}{ }^{2-}, \mathrm{HCO}_{3}{ }^{-}, \mathrm{SO}_{4}{ }^{2-}, \mathrm{Cl}^{-}\right.$and $\left.\mathrm{SiO}_{2}\right)$ and minor constituents $\left(\mathrm{PO}_{4}{ }^{3-}\right.$ and $\left.\mathrm{NO}_{3}{ }^{-}\right)$as well as some trace elements $(\mathrm{Fe}, \mathrm{Mn}$ and $\mathrm{Zn})$. Also, the bacteriological parameters as total coliform counts (M.P.N $/ 100 \mathrm{ml}$ ), total colony counts $\times 10^{2}$ (S.P.C/ml at $37^{\circ} \mathrm{C}$ ) and Triple Sugar Iron (TSI) were defined for selected twenty nine water samples which are uniformly distributed across the study area. The obtained data were then analyzed by statistical approach, in order to determine the origin of the contamination. The obtained results showed that, $89 \%$ of the Miocene groundwater samples are brackish water while the rest of the samples (11\%) are fresh water. Both the hypothetical salts combinations and Piper trilinear diagram indicate that there are great similarities of the hydrochemical composition between the drains and springs water as well as the Miocene groundwater which may reflect the same geochemical environment where the water is discharged. All selected drains and springs water samples as well as the majority of the Miocene (64\%) and 50\% of Nubian sandstone groundwater samples are often bacteriologically contaminated by total faecal coliform (Escherichia coli). There is a connection between the drain and springs water as well as the Miocene groundwater. The groundwater in the study area is unsuitable for drinking purposes under the ordinary conditions.
\end{abstract}

Keywords: Groundwater; Geological characteristics; Hydrochemical features; Bacteriological pollutants; Siwa Oasis

\section{Introduction}

Many people believe that the water will be the reason for the occurrence of coming wars in the twenty-first century. Where unfortunately, clean, pure and safe water only exists briefly in nature and is immediately polluted by prevailing environmental factors and human activities.

So, before water can be described as potable, it has to comply with certain physical, chemical and microbiological standards, which are designed to ensure that the water is palatable and safe for drinking (Tebutt, 1983). Where, potable water is defined as water that is free from diseases producing microorganisms and chemical substances deleterious to health (Ihekoronye and Ngoddy, 1985). For that, consequent to the realization of the potential health hazards that may result from contaminated drinking water, contamination of drinking water from any source is therefore of primary importance because of the danger and risk of water borne diseases (Fapetu, 2000 and Edema et al., 2001).

In many developing countries, availability of water has become a critical and urgent problem and it is a matter of great concern to families and communities depending on non-public water supply system. Conformation with microbiological standard is of special interest because of the capacity of water to spread diseases within a large population. Although the standards vary from place to place, the objective anywhere is to reduce the possibility of spreading water borne diseases to the barest minimum in addition to being pleasant to drink, which implies that it must be wholesome and palatable in all respects (Edema et al., 2001).

Corresponding Author: Yahia Gedamy, Hydrogeochemistry Department, Desert Research Center, Cairo, Egypt. E-mail:yahiagedamy2014@yahoo.com. 
In Africa, groundwater is a vital resource with nearly $80 \%$ of the continent's population relying on it as a main source of drinking water. However, in many parts of the continent, reaching basic health requirements is still a concern (Mengnjo et al., 2013).

The limitation of the water resources in Egypt coupled with the continuous population growth invokes a pressure on the regional resources especially water (Aly, 2015). So, now, the drinking and irrigation water in Egypt is one of the biggest problems. Egypt is endowed with numerous water resources, but an assessment of these resources, including their reliability, quality and sustainability has not been systematically carried out. With the increasing demands for water due to increasing population, urbanization and agricultural expansion, groundwater resources are gaining much attention, particularly in arid and semi-arid regions.

Due to the arid climate of the southern part of Egypt, oases groundwater is a most precious natural resource, providing reliable water supplies for the population of these oases (Aly et al., 2011).

Siwa contains unique geological features which can flourish geologic tourism (Sallam et al., 2018). Siwa has a unique environment, makes it a good place for medical tourism. Many peoples, suffered from joint and skin diseases, visit Siwa annually for natural therapy (Salman et al., 2018).

The groundwater is the key of life in this oasis, where there is no permanent or even ephemeral fresh water streams. The groundwater is under artesian conditions. It is available from the natural springs and free flowing wells tapping both the deep aquifer (the Nubian sandstone aquifer system, NSSAS) and the shallow aquifer (Tertiary carbonate aquifer system, TCAS), (El Hossary, 2013).

In the last few decades, the need for groundwater increased to cover the demands of agricultural, tourist and economic development in the oasis. Hundreds of water wells were constructed to meet the expansion of the cultivated area, urbanization activities and food industries (Salheen, 2013).

So, the only source of water in Siwa Oasis is groundwater, as rainfall is almost nil. So, the groundwater represents the sole source of water for different purposes in the study area as drinking, domestic and irrigation purposes. The lakes are the natural discharge areas for the drained water from the cultivated lands, natural springs and artesian wells.

The local population largely depends on the groundwater in the study area which is also used for irrigation and the oasis is continuing to grow. This means that both the freshwater demand and the landuse pressure are increasing. Due to the continuous agricultural expansion, urban development, and increased demands on limited water supplies, Egypt is compelled to look for unconventional water resources. One of the most important sources is groundwater in the western desert of Egypt. More water abstraction is currently taking place raising the dangers of overexploitation and deterioration of water quality in Siwa Oasis located in the Egyptian western desert (Aly et al., 2016).

As the water resources are fast dwindling as a result of rapid increase in world population and global warming. Therefore, discrete utilization of water resources and reuse of treated wastewater for different purposes have been recognized as the most effective ways of conserving the limited resources of fresh water (Kalkan et al., 2011). The presence of bacteria is the main indication of water contamination. Bacterial contamination of water is a public health concern because it causes numerous diseases and some aesthetic problems such as malodor in water. Organisms such as Escherichia coli, Shigella spp., Salmonella spp., Vibrio spp., and Cryptosporidium are known to be transmitted by water and cause ill health in communities consuming water contaminated by bacteria (Lukhele et al., 2010). The quality of irrigation water is an important issue due to its impact on crop production and soil quality as well as human and animal health. It gives a good indication of rock-water interaction and anthropogenic impact (Salman et al., 2018).

Because Siwa is a closed basin without any outlet for excess irrigation or seepage water and the presence of impermeable layer $4-10 \mathrm{~m}$ deep, accumulated drainage water raises the water table to 50 $150 \mathrm{~cm}$ from the soil surface and causes water-logging (Schakschouk, 2002). The drainage problem started to be effective as the irrigated areas increased.

Siwa was populated in historic times and has increased from 3,000 in 1840 to approximately 23,000 in 2009 (Abdulaziz et al., 2015), while in 2019, the total number of inhabitants in Siwa has reached 30,000 (Siwa Information Center, 2019). It covers an area of about 250,000 Feddans of which about 15,000 Feddans are currently cultivated. The main activity in Siwa Oasis is agriculture totally based on groundwater available from both dug wells and naturally flowing springs (El Hossary, 2013).

The people of Siwa involve a mixture of Berber, Bedouin, and Sudanese races and have their own local language, a Berber dialect that is unrelated to Arabic language. The main activities of the 
population in Siwa are the traditional agriculture (the main crops are dates and olives) together with some small industries such as olive oil extraction, olive pickling, date drying, and the production of carpets and kilims as well as industries related to tourism such as handicrafts (textile and basketry). In the period 1981- 1996, farmers invented their own drilling machine that enabled them to drill thousands of poorly designed wells in the fractured limestone aquifer. This led to a surplus of water supply which resulted in the formation of lakes at the lower part of each catchment along with continued loss of productive lands.

The human/landscape interaction in Siwa yielded a geo-environmental disaster on sustainable development on the whole country. In the last decades after 1970, wide areas inside the depression were reclaimed-soil for agriculture, but now the neighbored old cultivated land are covered by agriculture sewage forming too wide salt lakes encroachment destroying the agriculture in this closed depression, where the sewage water encroaches on the land destroying the good soil and historical agriculture, and the ecotourism (El Gammal, 2015).

There are several studies were devoted mainly for evaluating the groundwater potential and provide detailed characterization of groundwater quality in this region by some authors, among them; Aly (2001), Aly (2007), Aly et al. (2008), Aly et al. (2011), El Hossary (2013), Hedia (2015), Aly et al. (2016), Saleh et al. (2016), Farrag and Sediek (2017) and Salman et al. (2018).

In the present study, the objectives are (a) to show the geological characteristics of the shallow Miocene groundwater, (b) to delineate the hydrochemical characteistics of the Miocene groundwater in the study area, and (c) to study the bacterial contamination analysis of 29 selected samples collected in the active abstraction lakes, drains, springs in addition to the Miocene and Nubian groundwater wells, which are uniformly distributed across the study area was studied to determine the extent to which this water is contaminated with bacteriological pollutants or not, as well as (d) to determine the origin of the contamination and its spatial evolution and finally (e) evaluate the groundwater resources in the study area for drinking and irrigation purposes.

\section{Site description}

Siwa Oasis is considered the virgin and smallest oasis of the seven major important natural depressions located in the Western Desert of Egypt, where it sits in a closed structural eroded deep depression that reaches below sea level, varies in altitude between $\sim 1$ and $-18 \mathrm{~m}(-62 \mathrm{ft})$ and surrounded by barren highlands (limestone plateau) with altitude to $300 \mathrm{~m}$ above sea level. Also, the depression has an irregular elongated shape extending in an $\mathrm{E}-\mathrm{W}$ direction, where it is extending about $80 \mathrm{~km}$ from east to west with a width that varies between 9 and $28 \mathrm{~km}$ (about $5 \%$ of this area are now under cultivation, while the remaining area is mainly saline, rocky, or occupied by salty lakes). The total area of the oasis is about of $1088 \mathrm{~km}^{2}$. The land surface is undulated and contains narrow-flat lands cultivated mainly with palm and olive trees. The deeper portions of the depression floor are dominated by salty lakes surrounded by large areas of salty marches and sabkhas. The topographic features of the Oasis show a depression divided into four major catchments (i.e. El Maraki, Siwa, Aghourmi and Zeitoun). Each catchment is characterized by its own drainage natural lake, which receives the agricultural drainage water and the excess flowing groundwater from the natural springs and the private wells. The depression floor overlies Eocene limestone while, in the western part overlies the Cretaceous Nubia sandstone. Siwa Oasis is located in the northern part of the Western Desert of Egypt between the Qattara Depression and the Egyptian Sand Sea, about $60 \mathrm{~km}$ east of the Libyan border, about $400 \mathrm{~km}$ west of Bahariya Oasis and 306km south of the Mediterranean Sea (southwest Marsa Matrouh) and around $800 \mathrm{~km}$ west Cairo and occur mostly to the east of Agormy and administratively follows Matrouh Governorate. It is bordered on the north by the steep escarpment of the Miocene Marmarica Limestone Plateau and southwestern by a series of sand dunes of the Great Sand Sea attaining $150 \mathrm{~m}$ and $50 \mathrm{~m}$ (a.s.1) above mean sea level, respectively (El Hossary, 2013). It lies between latitudes $29^{\circ} 05^{\prime} 00^{\prime \prime} \mathrm{N} \& 29^{\circ} 19^{\prime}$ $00^{\prime \prime} \mathrm{N}$ and longitudes $25^{\circ} 12^{\prime} 00^{\prime \prime} \mathrm{E} \& 25^{\circ} 55^{\prime} 00^{\prime \prime} \mathrm{E}$ (Fig. 1). 


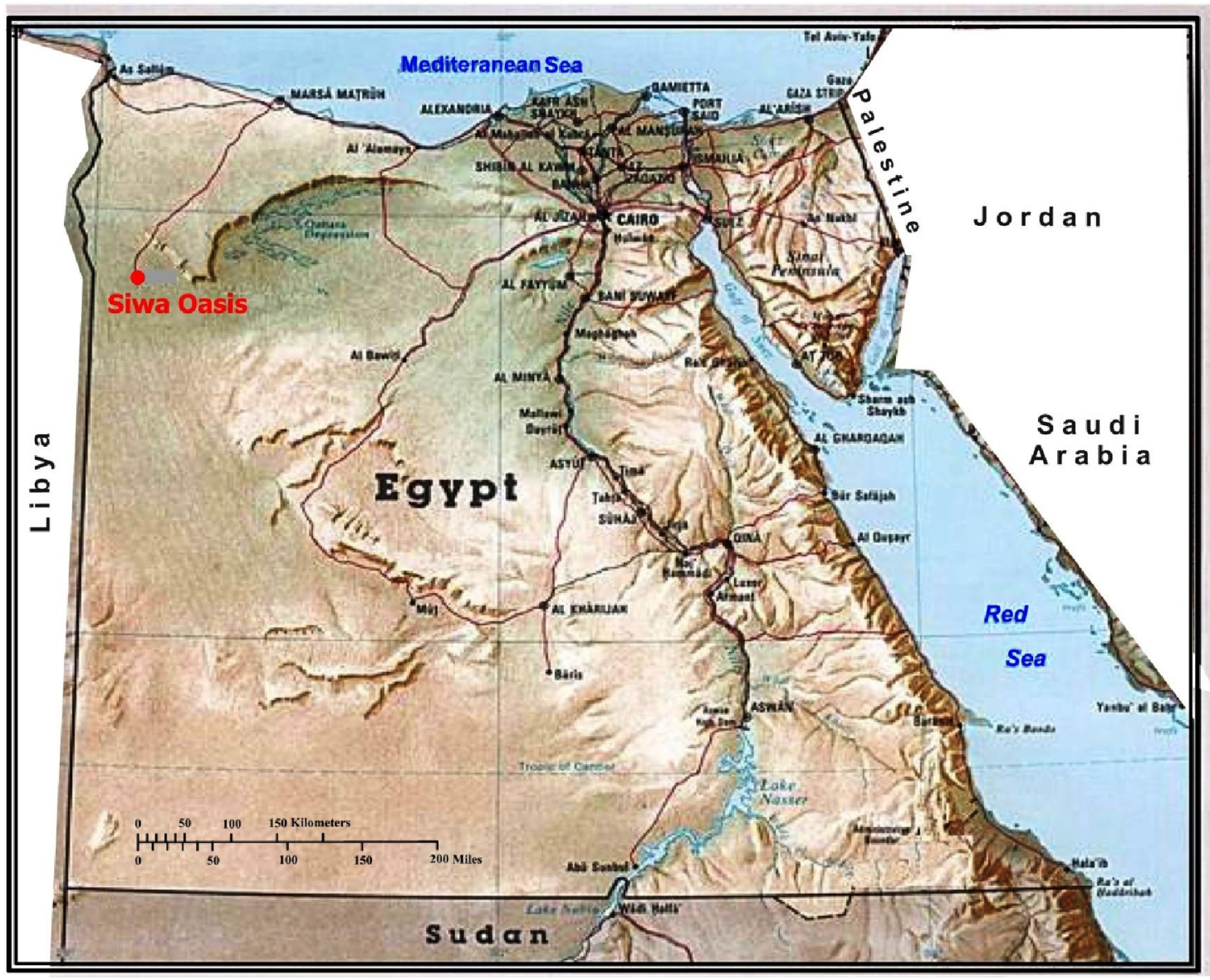

Fig.1: Situation of the study area

\section{Climate}

Siwa Oasis is characterized by a desert climate (arid to semi-arid conditions), where it displays short and mild winter season and a long hot and dry summer. The average minimum temperature recorded was $15^{\circ} \mathrm{C}$ in winter and a maximum of $38^{\circ} \mathrm{C}$ in summer (Abou El Magd and Faid, 2007). Rainfall is scarce (negligible rainfall) with an average annual rainfall of $13 \mathrm{~mm}$. The area has high evaporative conditions where, the evapotranspiration attains its minimum value $(62 \mathrm{~mm})$ during January but the maximum value $(283 \mathrm{~mm})$ is attained during July and the daily evaporation varies from $4.32 \mathrm{~mm}$ to $13.54 \mathrm{~mm}$. The climate is moderate to high humidity, where it is warmer and humid in summer than the other oases of similar latitude due to the intensive evaporation from the lake. Because the oasis lies in a depression, it is somewhat protected from the hot desert wind and evapotranspiration rates is slightly lesser than those in the surrounding desert environments (Farrag and Sediek, 2017).

\section{Materials and Methods}

A total of thirty seven water samples was obtained from a number of water sources, among which are lakes, drains, springs and wells at different localities at Siwa Oasis during 2018 (Fig. 2). The water samples were collected in sterilized water plastic containers. Each sample was divided into three parts; the first part is put in one liter to determine the major and minor constituents, the second part is put in $100 \mathrm{ml}$ and acidified with nitric acid to determine the trace elements and the third part is put in $100 \mathrm{ml}$ to determine the microbial pollutants. The collected water samples were stored in ice boxes and transported to the Desert Research Center laboratories for carrying out the required chemical and bacteriological analyses. 
The coordinates of the collected water samples were obtained using GPS instruments (model Garmin Etrex). Also, the physical parameters as $\mathrm{pH}$, temperature $\left(\mathrm{T}^{0} \mathrm{C}\right)$ and electrical conductivity $(\mathrm{EC})$ were measured in situ by pH meter (Jenway, model 3150) and EC meter (Jenway, model 470).

The other parameters were determined in the laboratories and included total dissolved solids (TDS), calcium $\left(\mathrm{Ca}^{2+}\right)$, magnesium $\left(\mathrm{Mg}^{2+}\right)$, sodium $\left(\mathrm{Na}^{+}\right)$, potassium $\left(\mathrm{K}^{+}\right)$, carbonate $\left(\mathrm{CO}_{3}{ }^{2-}\right)$, bicarbonate $\left(\mathrm{HCO}_{3}{ }^{-}\right)$, sulphate $\left(\mathrm{SO}_{4}{ }^{2-}\right)$, chloride $\left(\mathrm{Cl}^{-}\right)$which were analyzed according to Rainwater and Thatcher, 1960. Also, the concentrations of nitrate $\left(\mathrm{NO}_{3}{ }^{-}\right)$and phosphate $\left(\mathrm{PO}_{4}{ }^{3-}\right)$ were determined by colorimetric methods using UV/Visible spectrophotometer (Thermo-Spectronic 300) according to Fishman and Friedman, 1985, as well as the trace constituents (Fe, Mn and $\mathrm{Zn}$ ) were determined using an ICAP model (thermo 6500) according to ASTM, 2002.

The total viable bacterial counts (TVBCs) were performed within $24 \mathrm{~h}$ of the collection using the spread-plate method and standard Multiple Tube Fermentation Technique (MTFT), (APHA, 1998). The number of total and faecal coliforms was determined using the Most Probable Number (MPN) index and MacConkey broth media. The positive tubes were streaked on the Eosin Methylene Blue (EMB) agar plates. Microscopic examination was carried out to ensure gram-negative, non-spore forming rods (APHA, 1998). MPN of faecal streptococci was determined using azide dextrose broth at $37^{\circ} \mathrm{C}$ for $48 \mathrm{hr}$. Positive tubes were indicated by dense turbidity and confirmed using ethyl violet azide dextrose broth incubated at $37^{\circ} \mathrm{C}$ for $24 \mathrm{hr}$. (APHA, 1998). Nine multiple tube dilution technique using double and single strength Bromo-Cresol Purple MacConkey medium for detection of E.coli (Thermotolerant coliform, TTC) with production of yellow colour colonies on membrane filter at $44.5^{\circ} \mathrm{C}$. For differentiation between different species of enteric bacteria, sub culturing colonies on Triple Sugar Iron (TSI) were done for contaminated water samples.

The Shuttle Radar Topographic Mission (SRTM) DEM was employed to generate a hill shaded relief map through spatial analysis tool of ArcGIS v.10.4. The hill shaded map is used with geologic map (Conco, 1987) to extract the structural lineaments (faults and/or joints). These lineaments are illustrated on the DEM and the hill shaded relief maps (Figs.12 \& 13) along with the spatial distributions of the polluted drains, springs and groundwater wells to discuss their relationship. The maps and spatial distributions of this data were achieved through GIS environment.

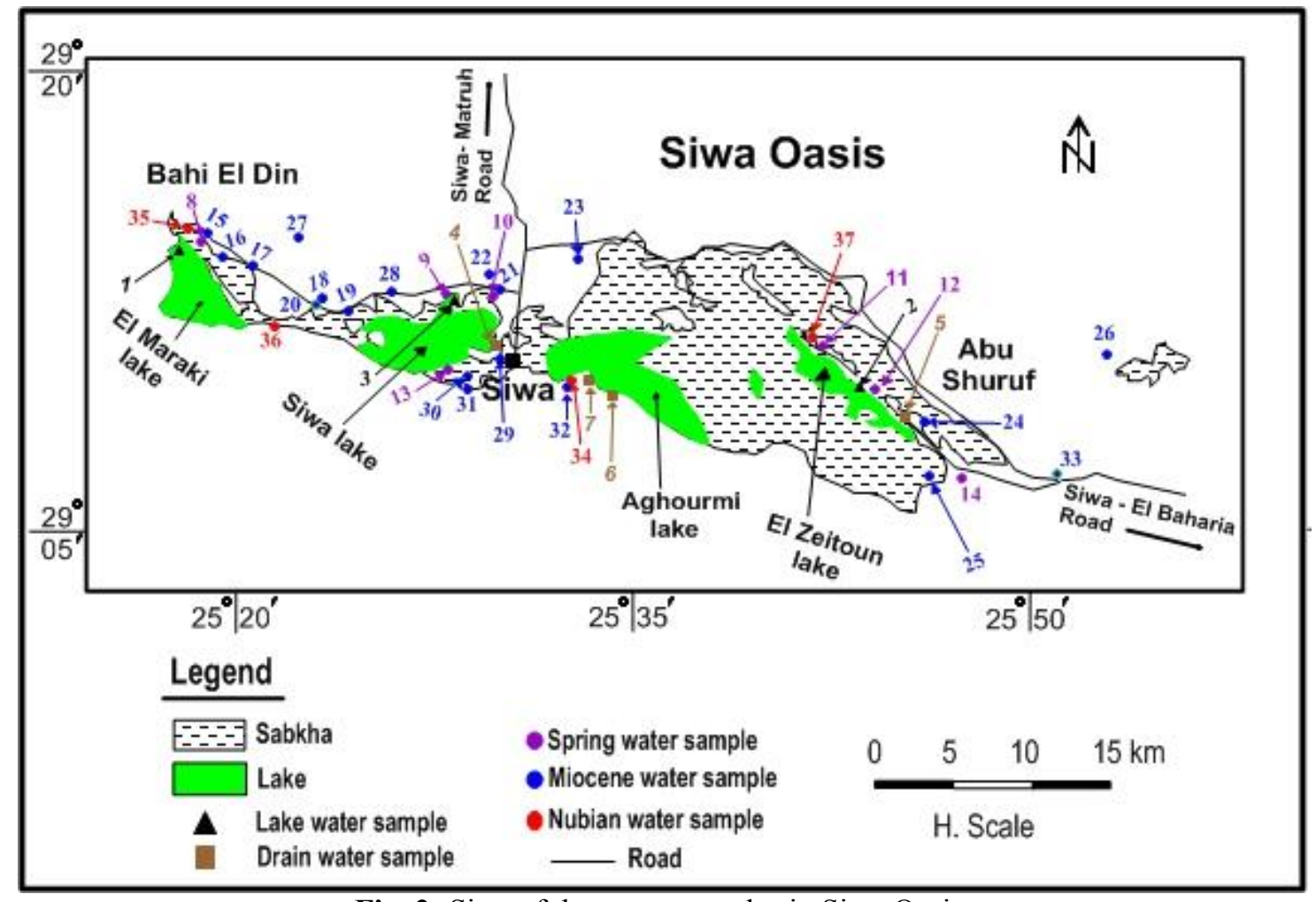

Fig. 2: Sites of the water samples in Siwa Oasis 


\section{Geomorphological, geological and hydrogeological settings \\ Geomorphological setting}

Siwa Oasis covers an area of $1088 \mathrm{~km}^{2}$. It was initiated as a result of the structural (folding followed by faulting) and erosional effect. The location of the oasis in the northern portion of the Western Desert made the depression as a natural discharging locality for the different aquifers through springs and wells. The surface of the depression and its surroundings reveals the following geomorphologicl units (Fig.3):

\section{The limestone plateau}

The Marmarica limestone plateau bounds the oasis from the north with a steep escarpment. This steepness decreases downward due to the presence of shale and sandstone intercalations. This escarpment reveals many indentations (Monqars) and embayments. The surface of the plateau attains $150 \mathrm{~m}$ (a.s.1) and gently sloping towards the north. It is dissected by short drainage lines draining the floodwater to the depression. The oasis is separated from the plateau by hilly areas consisting mainly of carbonate rocks.

\section{The piedmont plain}

The piedmont plain covers the area between the foot slope of the escarpment to the north and the sand dunes to the south. It lies under sea level and can be distinguished into two subunits; the slope and the mid portion. The piedmont slope is gently sloping southward and covered with talus deposits, green shale and gypsum with alluviation and drift sand. On the other hand, the mid portion covers the area between the slope and the lakes. It has an elevation range between -8 and $-15 \mathrm{~m}$ and its surface is occupied by salty soil. This unit can be distinguished into finer geomorphic units; the residual hills, the cultivated land and the water lakes. The residual hills reveal mesas and butt forms and composed mainly of hard limestone of G. El Mawta (27m), G. Khushi (36m), G. Siwa (38m), G. Khamisa (107m) and G. El Dakrour $(80 \mathrm{~m})$. They believed to represent a tectonically detached block of the marmarica limestone plateau. The cultivated lands are highly salinized and hard. On the other hand, the depression comprises six water lakes, Tameira, El Moaser, Zeitoun, Aghourmi, Siwa and El Maraki. They have different trends reflecting structural control.

\section{The elevated plain}

It occupies the southern portion of the oasis. It exhibits Miocene isolated hills (G. Tobtah, 86m and G. Mortazak, 85m) and the northern belt of the Great Sand Sea.

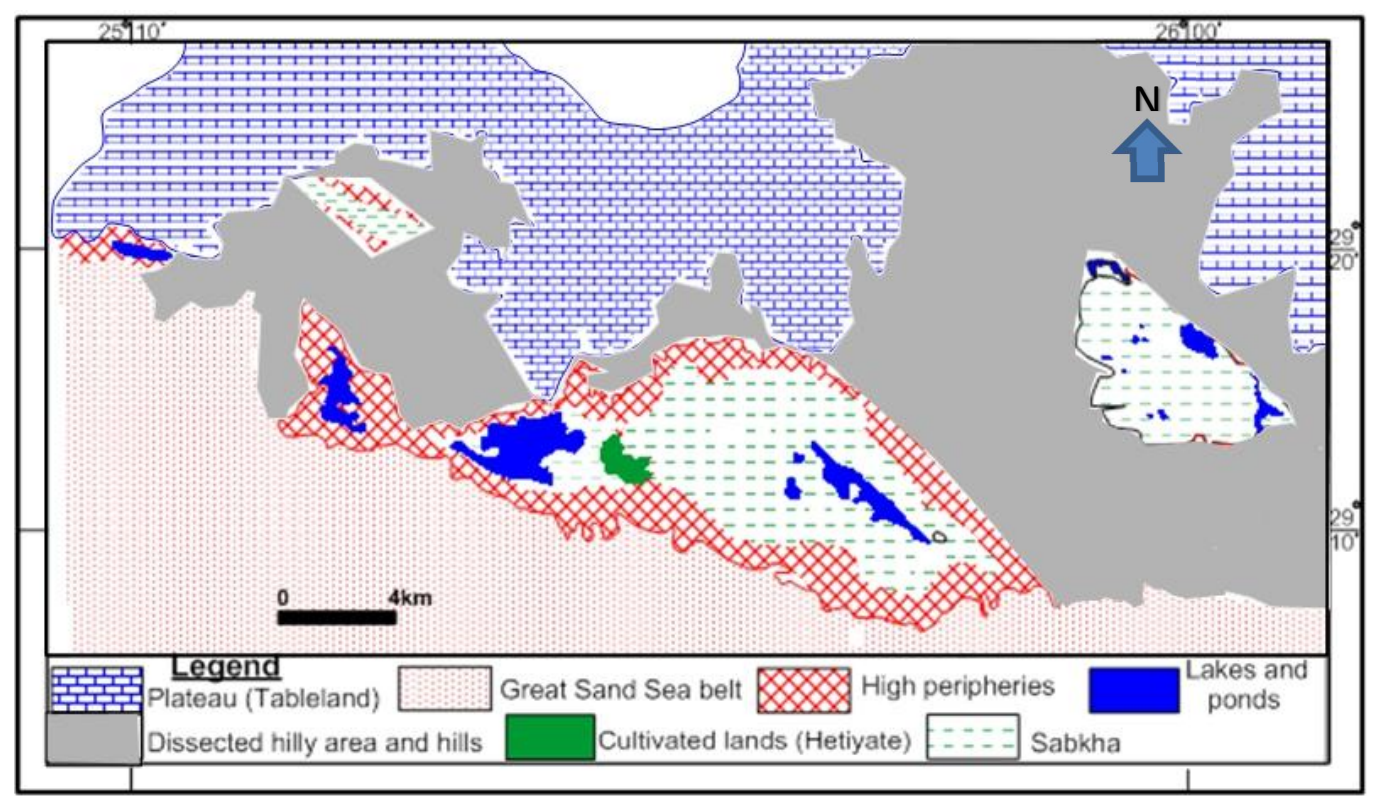

Fig. 3: Geomorphological map of the important features developed in Siwa oasis and the surrounding area 


\section{The geological setting}

To clarify the hydrogeologic conditions of the Siwa Oasis, the geologic setting of the oasis should be discussed. It will be discussed under two topics; the lithostratigraphy and structural setting (Fig. 4):

\section{The lithostratigraphy}

The surface and subsurface of Siwa Oasis comprise different rock units. These units cover geologic periods ranging in age from Cambrian to Quaternary. This succession had underlain by granitic rocks. The phanereozoic rocks of the Siwa Oasis area and its environs are discussed in the following:

\section{Surface stratigraphy}

The surface geology of the oasis is occupied mainly by the Quaternary deposits consisting of sabkhas (silt, clay and evaporates deposits) and sand dunes. The oldest rocks cropping out in the area is the Middle Eocene-Mokkatam Group (white chalky limestone, gray shale and neritic limestone beds), which is exposed in the southeastern part of the area. Within and around the northern escarpment bordering the depression, there are several and erosional drainage lines that mostly influenced by the fracture systems trending, mainly, in a NW-SE and NE-SW directions. The surface of the oasis and its environs comprise different rock units of different ages. At the environs of Siwa oasis, the Middle Eocene chalky limestone is exposed with an exposed thickness of $75 \mathrm{~m}$ west Ain Timeira and this unit is overlain by quartzitic gravel and silisified wood of Lower Miocene Moghra Formation (Moghra Formation, composed of continental to shallow marine silci-clastic sequence, including shale, siltstone and white sandy carbonate beds, with abundant silicified wood). In subsurface the Moghra Formation, a clastic fluviomarine delta-front sequence of Early Miocene that grades laterally to marine facies (Said, 1990), unconformably overlies the Upper Eocene.

In the area of the depression, the Marmarica Formation of Middle Miocene ( $94 \mathrm{~m}$ thick) forms the greater part of Siwa Oasis. This formation is mainly consisting of limestone, dolomite and shale (Upper Miocene, Marmarica Formation composed of grayish white calcarenites with few shale interactions, followed upwards by white limestone rich in fossils). It mainly forms the northern scarp (78m height) and many of the hills at Gebel El Dakrour, Mortazak, Zomaq, El Mawta and Khameisa. The surface thickness attains $78 \mathrm{~m}$ at the scarp and $94 \mathrm{~m}$ all over the depression (El Gindy and El Askary, 1969).

Tertiary rocks are covered by the Quaternary deposits that are represented in Siwa Oasis by alluvium and aeolian deposits. The Quaternary deposits have a thickness range from $2 \mathrm{~m}$ to $3 \mathrm{~m}$ soil zone that is replaced by salt or sabkha at the proximity of the lakes. The area around the lake constitutes salt crust (Korsheef) or sabkha. The planting of this land needs washing for the soil salts leading to the overflow of the oasis.

\section{The subsurface stratigraphy}

The subsurface stratigraphic sequence consists of a sedimentary succession of Paleozoic, Mesozoic and Cenozoic strata reaching about $3400 \mathrm{~m}$ thick. It is characterized by two main depositional cycles of clastic and carbonate (Table 1 and Figure. 4). The first cycle of clastic facies dominates the oldest sedimentary rocks and comprises the Paleozoic and Mesozoic formations. The second cycle of carbonate facies includes the Tertiary Eocene and Miocene formations. The whole stratigraphic sequence of Paleozoic, Mesozoic and Cenozoic overlying the basement rocks is affected by a number of NW-SE, NE-SW, E-W and N-S oriented normal faults (Said, 1962 and Afifi, 2005). These faults are, for the most part, the reason behind the appearance of Siwa springs (Shata, 1982) and the change in lithofacies and formation thicknesses.

The subsurface of the area of Siwa oasis and its environs was penetrated by some deep wells. The succession of these wells (Siwa 1, Zeitoun, Desouki and Kohla) reveals rocks related to the Paleozoic, Mesozoic and Cenozoic Eras (Table 1): 
Table 1: A generalized section of the geologic formations in Siwa Oasis, Egypt (compiled after Ibrahim, 1991; EGPC, 1992 and Afifi, 2005)

\begin{tabular}{|c|c|c|c|c|c|}
\hline Era & Age & : & $\begin{array}{l}\text { Average } \\
\text { Thickness }\end{array}$ & Lithic description & $\begin{array}{l}\text { Depositional } \\
\text { environment }\end{array}$ \\
\hline \multirow{3}{*}{ 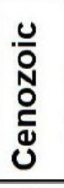 } & \multirow{2}{*}{ Miocene } & \multirow{2}{*}{ IT } & \multirow{2}{*}{$250 m$} & Limestone with marl (Marmarica Fm.) & Shallow marine \\
\hline & & & & Sandstone, siltstone, shale (Moghra Fm.) & Fluvio-Marine \\
\hline & Eocene. & 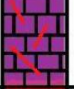 & $350 \mathrm{~m}$ & $\begin{array}{l}\text { Limestone intercalated with shale, } \\
\text { marl, evaporites beds(Mokattam Gr.) }\end{array}$ & Shallow marine \\
\hline 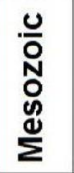 & Cretaceous & 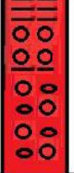 & $600 \mathrm{~m}$ & $\begin{array}{l}\text { Sandstone with shale and carbonate } \\
\text { intercalations (L. Cretaceous), overlain } \\
\text { by impermeable layer of carbonaceous } \\
\text { shale and argiliceous limestone (U. } \\
\text { Cretaceos) }\end{array}$ & $\begin{array}{c}\text { Shallow marine, } \\
\text { near shore }\end{array}$ \\
\hline \multirow{4}{*}{$\begin{array}{l}\frac{U}{0} \\
\frac{N}{0} \\
\frac{d}{\pi} \\
0\end{array}$} & Carboniferous & & $912 \mathrm{~m}$ & $\begin{array}{l}\text { Sandstone with shale and } \\
\text { limestone }\end{array}$ & $\begin{array}{l}\text { Near shore, } \\
\text { Continental }\end{array}$ \\
\hline & Devonian & 퐁 & $347 \mathrm{~m}$ & $\begin{array}{l}\text { Mudstone, siltstone, carbonaceous } \\
\text { sandstone,limestone\&dolomite }\end{array}$ & $\begin{array}{l}\text { Fluviatile, Continent } \\
\text { al, Shallow marine }\end{array}$ \\
\hline & Silurian & $\because 8$ & $626 \mathrm{~m}$ & Mudstone and siltstone (Kohla Fm.) & Fluviatile, Marine \\
\hline & $\begin{array}{l}\text { Ordovician/ } \\
\text { Cambrian }\end{array}$ & $\begin{array}{l}00 \\
00\end{array}$ & $315 \mathrm{~m}$ & $\begin{array}{l}\text { Sandstone Intercalated with shale and } \\
\text { siltstone beds }\end{array}$ & Continental \\
\hline \multicolumn{2}{|c|}{ Pre-Cambrian } & & $?$ & \multicolumn{2}{|c|}{ Basement complex, Granite, Gneisses } \\
\hline
\end{tabular}

\section{The Paleozoic rocks}

The Paleozoic rocks overly directly the Precambrian rocks (Pegmatites). These rocks are mainly alternation of sandstone, shale and sands with a thickness range between $2177 \mathrm{~m}$ and $2506 \mathrm{~m}$. They are related to Cambrian - Ordovician (the thickness ranges between $127 \mathrm{~m}$ and $315 \mathrm{~m}$ ), Silurian (the thickness ranges between $352 \mathrm{~m}$ and $406 \mathrm{~m}$ ), Devonian (the thickness ranges between $660 \mathrm{~m}$ and $1209 \mathrm{~m}$ ), and Carboniferous (the thickness ranges between $591 \mathrm{~m}$ and $826 \mathrm{~m}$ ). The variation of the thickness of the different age reveals is referred to paleogeography of the area.

\section{The Mesozoic rocks}

The Mesozoic rocks of Siwa area are represented by the Cretaceous rocks. These rocks were distinguished into the Lower Cretaceous sandstone (the thickness ranges between $175 \mathrm{~m}$ and $612 \mathrm{~m}$ ), and Upper Cretaceous; Cenomanian, Turonian, Santonian, Campanian and Maestrichtian. The Upper Cretaceous rocks are consisting of alternation of sandstone, sands, sandy limestone of Cenomanian age (the thickness ranges between $163 \mathrm{~m}$ and $360 \mathrm{~m}$ ) and carbonate rocks (limestone and dolomites) and shales of Turonian - Maestrichtian age (the thickness ranges between $69 \mathrm{~m}$ and $230 \mathrm{~m}$ ). Tertiary rocks are covered by the Quaternary alluvium and eolian deposits that constitute $2-3 \mathrm{~m}$ soil zone that is replaced by salt or sabkha at the proximity of the lakes. In Egypt, the clastic fluviomarine Lower Cretaceous sediments between the crystalline basement and the Upper Cenomanian carbonates are known as the Nubian Sandstone (General Petroleum Company (GPC), 1991). Beneath Siwa, this sandstone is $2,500-3,000 \mathrm{~m}$ thicker and acts as a single groundwater system that is usually encountered $500-700 \mathrm{~m}$ below ground surface. The upper section of this system represents the main freshwater provider in the eastern part of Siwa Oasis as it is completely eroded in the western part. 


\section{The Cenozoic rocks}

The Cenozoic rocks are represented by Tertiary rocks and Quaternary deposits. The Tertiary rocks are mainly carbonates (limestone and dolomites). They can be distinguished into Eocene and Miocene - Pliocene. The maximum thickness of the Eocene rocks is $463 \mathrm{~m}$ and that of the Miocene Pliocene is $248 \mathrm{~m}$.

The Quaternary deposits are represented by a few meters $(2-3 \mathrm{~m})$ covering the Tertiary deposits. These deposits are mainly clays representing the weathering products of the country rocks (carbonates). They constitute the cultivated soils in the depression. The sand dunes which represent the northern periphery of the Great Sand Sea (GSS) are also bounded Siwa depression from the south.

\section{The structural setting}

The characteristics of the sedimentary succession (tectonic evolution) reveal that Siwa Oasis passed in its geologic history by complicated phases (a complicated geologic history). These phases vibrated between uplifting and subsidence through folding, horsts and grabens. This reflects the variation of the thickness of the different formations (Rizkalla and Awad, 1990). The concerned Oasis occupies a regional synclinal fold trending NNW-SSE. This was revealed from the study of Landsat images (El Shazly and Abdel Hady, 1976). The area of the oasis exhibits also the dominance of the structural lineaments especially those which extend in a NW-SE and ENE-WSW direction. El Zeitoun and Aghourmi ponds are controlled by the two trends. The presence of these lineaments plays an important role in the existence of the springs of Siwa Oasis and also in the hydraulic connection between the different aquifers.

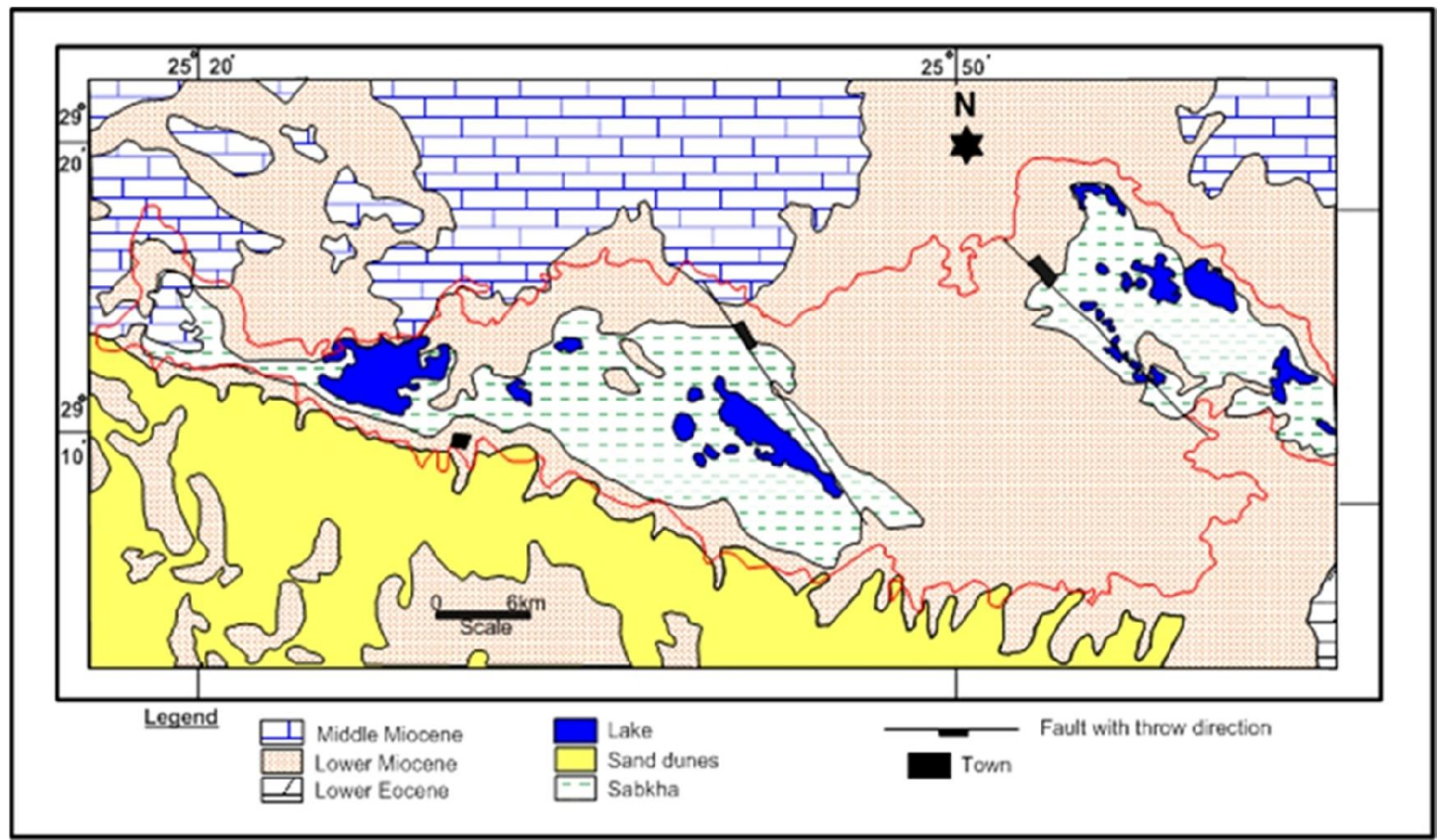

Fig. 4: The geological map of Siwa Oasis area (After Conco, 1987)

\section{The hydrogeological setting (water bearing formation)}

In Siwa Oasis the groundwater is presented in different water bearing formations. These formations are; the Miocene fractured limestone, the Eocene fractured limestone and the Cretaceous Nubian sandstone form. The hydrogeologic characteristics of these formations are discussed in the following (Figs. 5, $6 \& 7$ ); 


\section{The Tertiary carbonate aquifer system (TCAS):}

The Tertiary carbonate aquifer system is represented by the Miocene and Eocene water bearing formations (Table 1). It is composed of carbonate materials (limestone and dolomite) intercalated with shale, siltstone, sandstone and evaporates deposits in some localities, with a thickness of 450-600m (about $550 \mathrm{~m}$ in average). The aquifer system is under confining conditions (El Hossary, 2013). It is tapped by a large number of hand-dug and drilled wells.

The Tertiary carbonate aquifer system overlying the Nubian sandstone aquifer. The fractured carbonate zones are separated from the underlying Nubian sandstone by the low permeability shale and clay layer. This layer acts as aquitard and its thickness varies between 60 in the west and $250 \mathrm{~m}$ in the east (El Hossary, 2013).

The principal source to recharge the aquifer system is through the upward leakage of groundwater from the NSSAS (Ibrahim, 1991and Dahab, 2004). In other words, the recharge to the fractured carbonate aquifer underneath Siwa Oasis is largely disputable between local recharge from the deep Nubian Sandstone aquifer and surface recharge at a faraway catchment area near Gebel Akhdar, Libya (El-Shazly and Abdel Mogheeth 1991). The discharge rate of the aquifer reaches $442000 \mathrm{~m}^{3} /$ day and the quality of groundwater varies, greatly, from place to place based on the penetrated lithofacies type (Abdel Mogheeth, 1996).

Alternatively, the groundwater head in the carbonate aquifer varies in average between 50 and $60 \mathrm{~m}$ (a.m.s.l.) that shows a considerable difference to the pressure head in the Nubian Sandstone aquifer. Such a hydrologic setting favors a dominant local recharge to the carbonate aquifer via the upward leakage from the Nubian Sandstone aquifer through fault plains and the developed fracture system. In addition, the high flux springs developed along major fault plains and tapping the carbonate aquifer (e.g., Abu Shrouf with a natural flow of $9,600 \mathrm{~m}^{3} /$ day) introduce an obvious evidence to the in situ recharge to carbonate aquifer. Other sources of recharge to the carbonate aquifer are assumed to occur through water influx from surface water runoff during Post-Middle Miocene time (El Hossary, 1999).

\section{The Miocene Carbonate aquifer}

The Miocene fractured limestone occupies the floor of the depression under the surface cover. This aquifer attains a thickness of about $250 \mathrm{~m}$ representing by medium hard to hard limestone, white, sandy, and siliceous downward with intercalations of shale and marl. These intercalations don't exceed $5 \mathrm{~m}$ and may be initiated aquiclude layers separating the two units of water bearing formations (Abdel Mogheeth, 1996).

The field survey of the private wells reveals that the shallow wells $(<40 \mathrm{~m}$ depth) have low yield attains $240 \mathrm{~m}^{3} /$ day (El Hossary, 1999). On the other hand, the wells with depths less than $150 \mathrm{~m}$ reveal a zone of $80 \mathrm{~m}$ thick, consisting of hard limestone inter-bedded with shale have a yield of $960 \mathrm{~m}^{3} / \mathrm{day}$.

The productivity of this aquifer has varied from place to another due to the variation of the fracture density and the degree of its connection with the source of recharge (Nubian Sandstone aquifer).

In general, most of the shallow wells that increase 1100 wells are relating to Miocene aquifer and having a discharge of 100 million $\mathrm{m}^{3} /$ year. The different drillings of RIGW (1996 - 1999) reveal different zones of fractures within the carbonate aquifers. They distinguish five zones of fractures. These zones have groundwater with different quality and quantity reflecting separate recharge for each zone. The two zones, which encountered at depths of $60 \mathrm{~m}$ and $100-130 \mathrm{~m}$ are expected to be Middle Miocene aquifer.

\section{The Eocene Carbonate aquifer}

In the subsurface the Eocene carbonates (limestone and dolomitic limestone with gypsum streaks) attain 390m thicker at Siwa Oasis. According to the succession of Zeitoun 1 well, which lies in the area of the depression; the third, fourth and fifth zones of the fractures, which are recorded in Ghazalat well, lay within the concerned aquifer. These zones occupy the intervals $220-250 \mathrm{~m}, 340-370 \mathrm{~m}$ and $450-$ $480 \mathrm{~m}$, respectively. These zones produce water amounts $30 \mathrm{~m}^{3} / \mathrm{h}, 90 \mathrm{~m}^{3} / \mathrm{h}$ and $80 \mathrm{~m}^{3} / \mathrm{h}$. This means that most of the natural springs issued in subsurface from the $3^{\text {rd }}$ zone. This zone was reached at the intervals $248-520 \mathrm{~m}$ and $550-588 \mathrm{~m}$ in Zeitoun 1 and Siwa 1 wells, respectively. The presence of different water quality within one formation reflects the upward of water through fractures look like tubes. These tubes are separated and the variability of the quality of the water reflects the characteristics of each zone. 


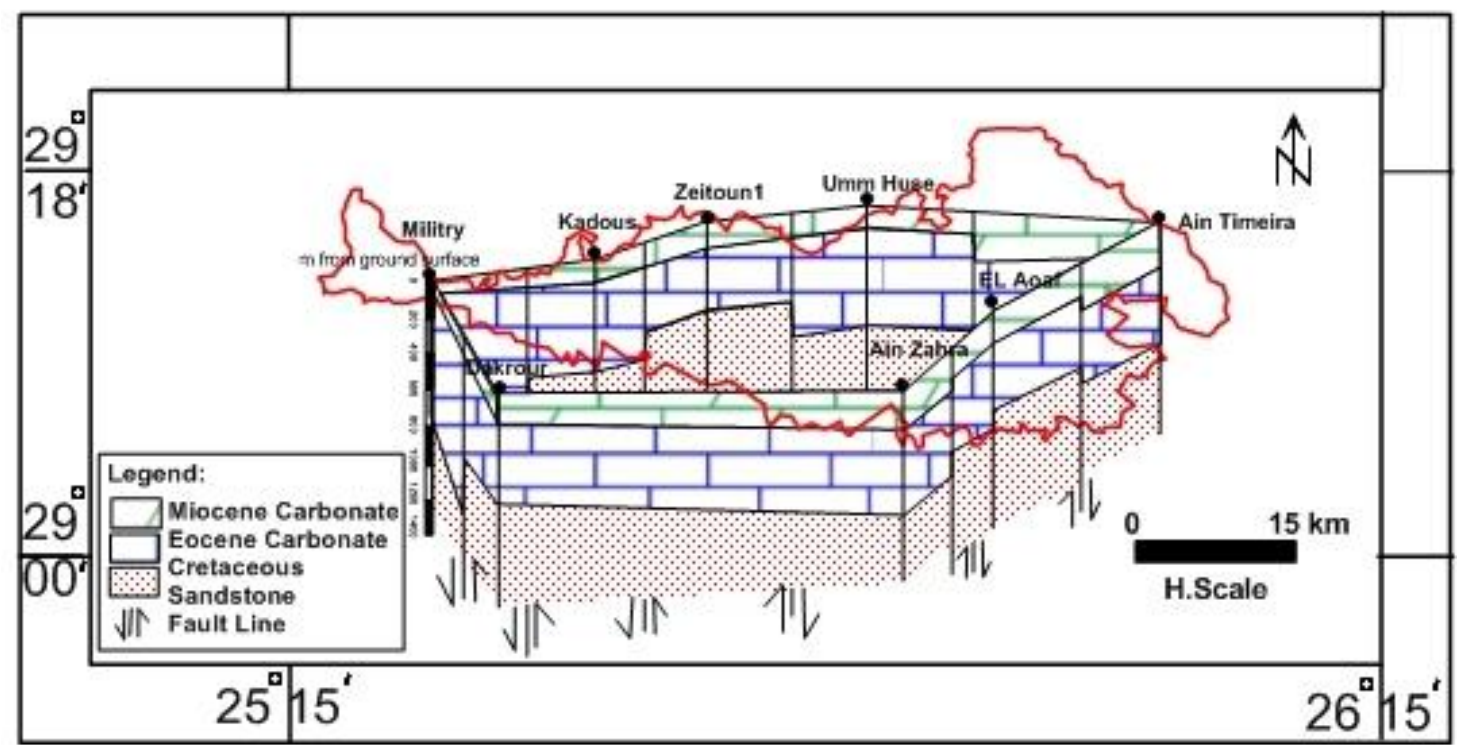

Fig. 5: Panel Diagram, showing the distribution of the aquifers in Siwa Oasis (Modified after Aggour and Faid, 2006).

\section{The Nubian sandstone aquifer system (NSSAS):}

The Nubian sandstone aquifer system (NSSAS) includes the water bearing series located between the Pre-Cambrian basement rocks and the Upper Cretaceous shale and marl layers, with a thickness of about $2600 \mathrm{~m}$ in average and belongs to the Mesozoic and Paleozoic age (Ibrahim, 1991; DGWG/EPIQ, 1998 and El Hossary, 1999). The upper zone of the Nubian Sandstone aquifer in Siwa Oasis has a thickness of about $500 \mathrm{~m}$ and is saturated with fresh water. The net sand thickness of this aquifer decreases northward and westward. The water pressure head of the Nubian Sandstone aquifer ranges between $80 \mathrm{~m}$ in the western part of the Siwa area (where shallow wells and springs exist) and $120 \mathrm{~m}$ in the east. The aquifer system is mainly formed of continental sandstones intercalated with minor shales and clays of deltaic and shallow marine origin. The aquifer is under confining conditions, characterized by high hydraulic parameters (Ezzat, 1974 and Ibrahim, 1991). The aquifer system is recharged from local rainfall that was prevailed during the pluvial times in the outcrop areas of the aquifer system (Sonntag, 1984 and Abed El Samie et al., 2006). Discharge occurs naturally through fault planes to the overlain carbonate aquifer (Ibrahim, 1991, Dahab, 2004) and artificially by the drilled wells.

The Cretaceous Nubian Sandstone aquifer represents the main source of fresh water supply in Siwa Oasis. This formation, which contains fresh water is related to Cenomanian and Lower Cretaceous as recorded from deep wells (Fig. 6). The hydraulic data of the above mentioned productive zone reveal the potentiometric level higher in the eastern and southern areas than in the western and central zone. It ranges in the first between $108 \mathrm{~m}$ (Tameira well) and $115 \mathrm{~m}$ (El Khashaby) and in the second between $45 \mathrm{~m}$ and $86 \mathrm{~m}$ (El Gerba). This reflects the presence of the aquifer in separate pockets as a result of the structural control. This is assured by the high decrease of the water level in the western portion of the oasis as a result of the high exploitation rates (Fig.7).

In fact, the contradicting age dating and wide range of ages reported to groundwater from the Nubian aquifer as discussed earlier lead to consider appreciable recharge or at least mix with water from the fluvial environment dominated at the Post-Miocene time in Egypt. This explains the presence of good quality parts of the carbonate aquifer and notable signs of water erosions in carbonates and other surface units such as old channels, dry gorges, and cavities along Siwa-Matruh road (El Hossary, 1999).

The dominant groundwater flow in Siwa area follows WNW direction with two major local flow systems encountered in the vicinity of Maraqi and Siwa lakes. These local flow systems are associated with discontinuity in the hydrostratigraphic units that correlate with the extensional faulted bedrocks, 
and such setting strongly supports the theory that the area is a structurally controlled tectonic depression (El Askary, 1969; Mohammad et al., 1999).

Monitoring the groundwater levels in shallow and deep wells throughout Siwa Oasis indicated direct hydraulic interaction between the Nubian Sandstone aquifer and the overlying carbonate aquifer (El Hossary, 1999).

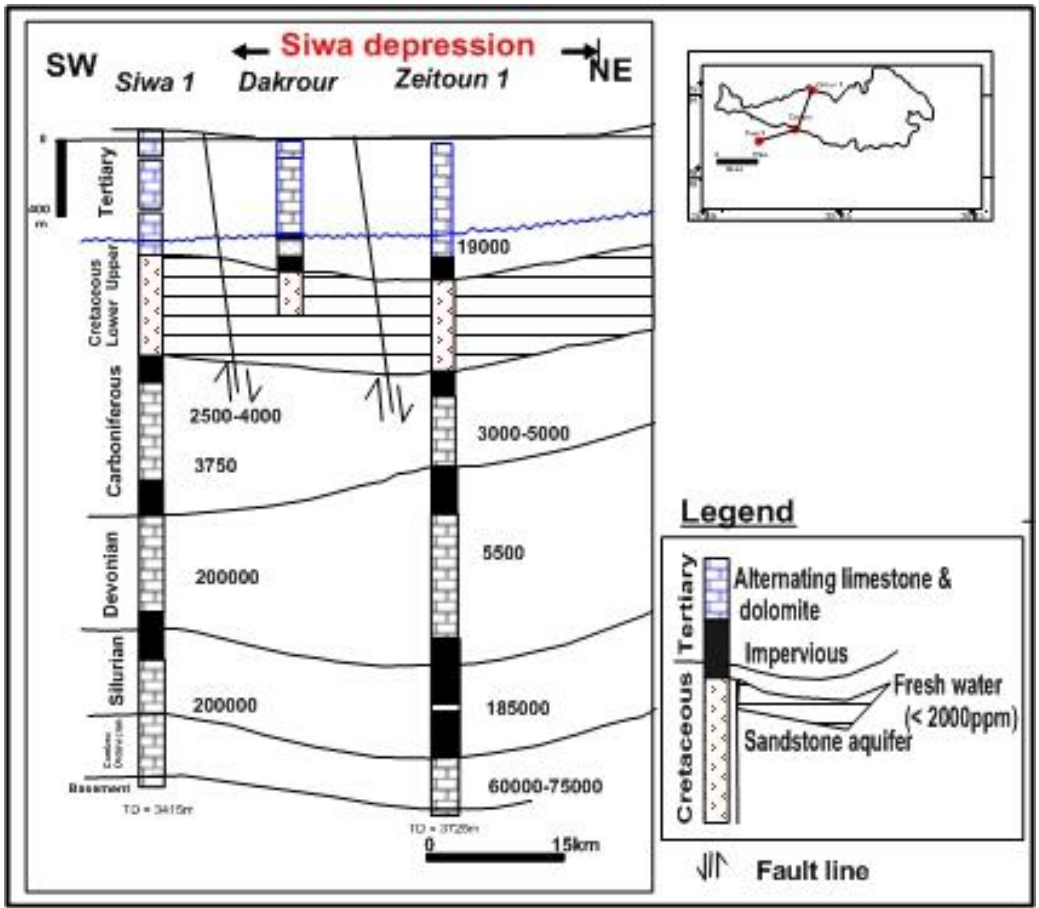

Fig. 6: NE-SW Hydrogeological cross section at Siwa Oasis (Modified after GPC, 1991)

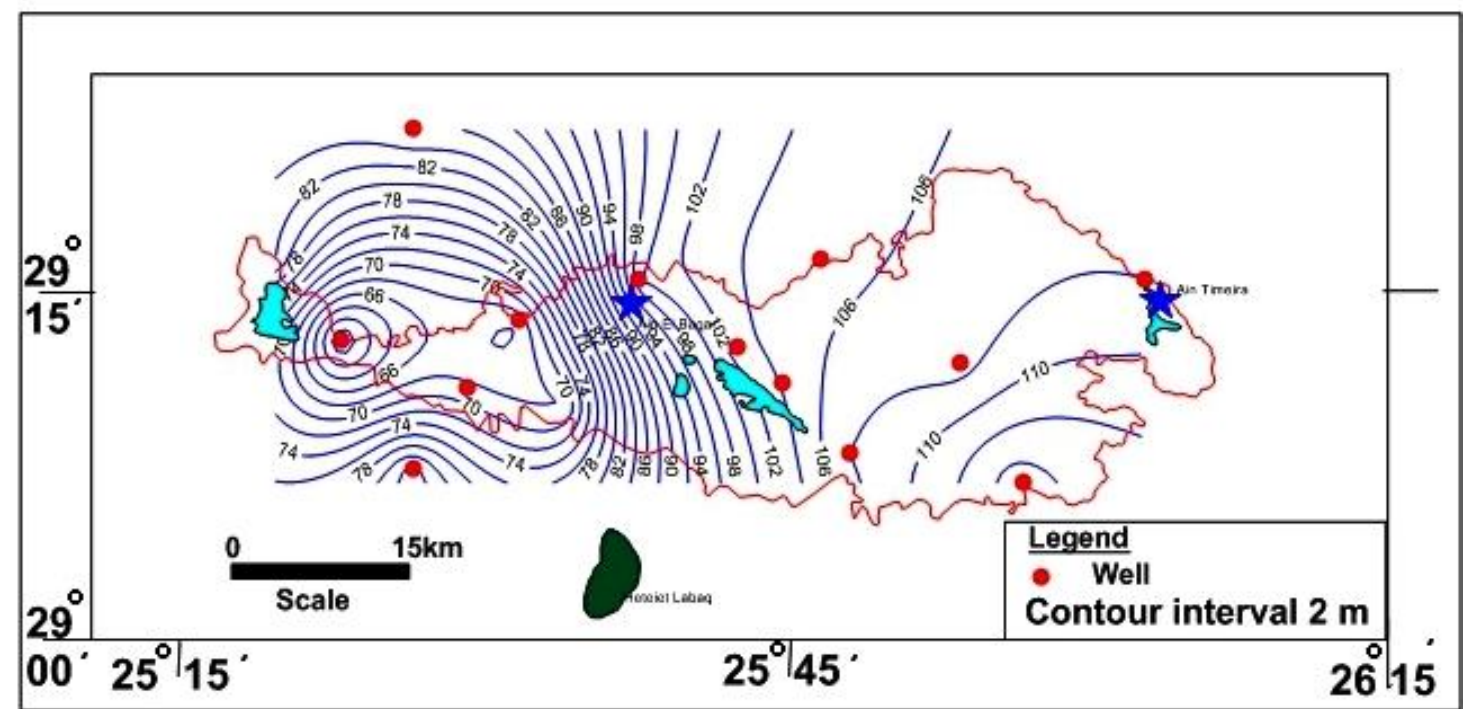

Fig.7: Potentiometric level map of the Nubian Sandstone groundwater at Siwa Oasis (Modified after Aggour and Faid, 2006).

\section{Groundwater Discharge}

Water wells and springs are the only water supply available in Siwa Oasis (Fig.8) with the majority tapping the shallow carbonate aquifer at depths between less than 10 and $120 \mathrm{~m}$ (all these shallow wells are poorly designed with no casing or control valves) and few deep wells $( \pm 1,000 \mathrm{~m})$ that pump a total 
of $400,000 \mathrm{~m}^{3} /$ day, which were flowing continuously to meet the water demands for agriculture and municipal uses (Abdulaziz and Faid, 2015), only about $60 \%$ of this water was used for irrigation and the rest was diverted to the poor drainage network ending finally in the lakes. Where, the total number of hand dug wells and springs are about 1100 giving a total discharge of about 130 million $\mathrm{m}^{3} /$ year. From this water, about 79 million $\mathrm{m}^{3} /$ year is productive (consumed through evapotranspiration) while the rest is lost to the lakes where it partially evaporates (RIGW, 2012). This has led to a continuous loss of productive lands and drainage problems in the surroundings of the lakes.

In general, the groundwater potential yield (sustainable) of the Siwa Oasis is estimated to be $500,000 \mathrm{~m}^{3} / \mathrm{d}$ (El Hossary, 1999), i.e., 130 million $\mathrm{m}^{3} /$ year (El Hossary, 2013). This amount is obtained, either directly from wells tapping the Nubian Sandstone aquifer only or from both the Nubian and the fractured limestone formation through the fractures which serve as paths to the groundwater contained in the Nubian. However, due to the continuous unlicensed drillings 51 million $\mathrm{m}^{3} /$ year is lost in the lakes (El Hossary, 2013).

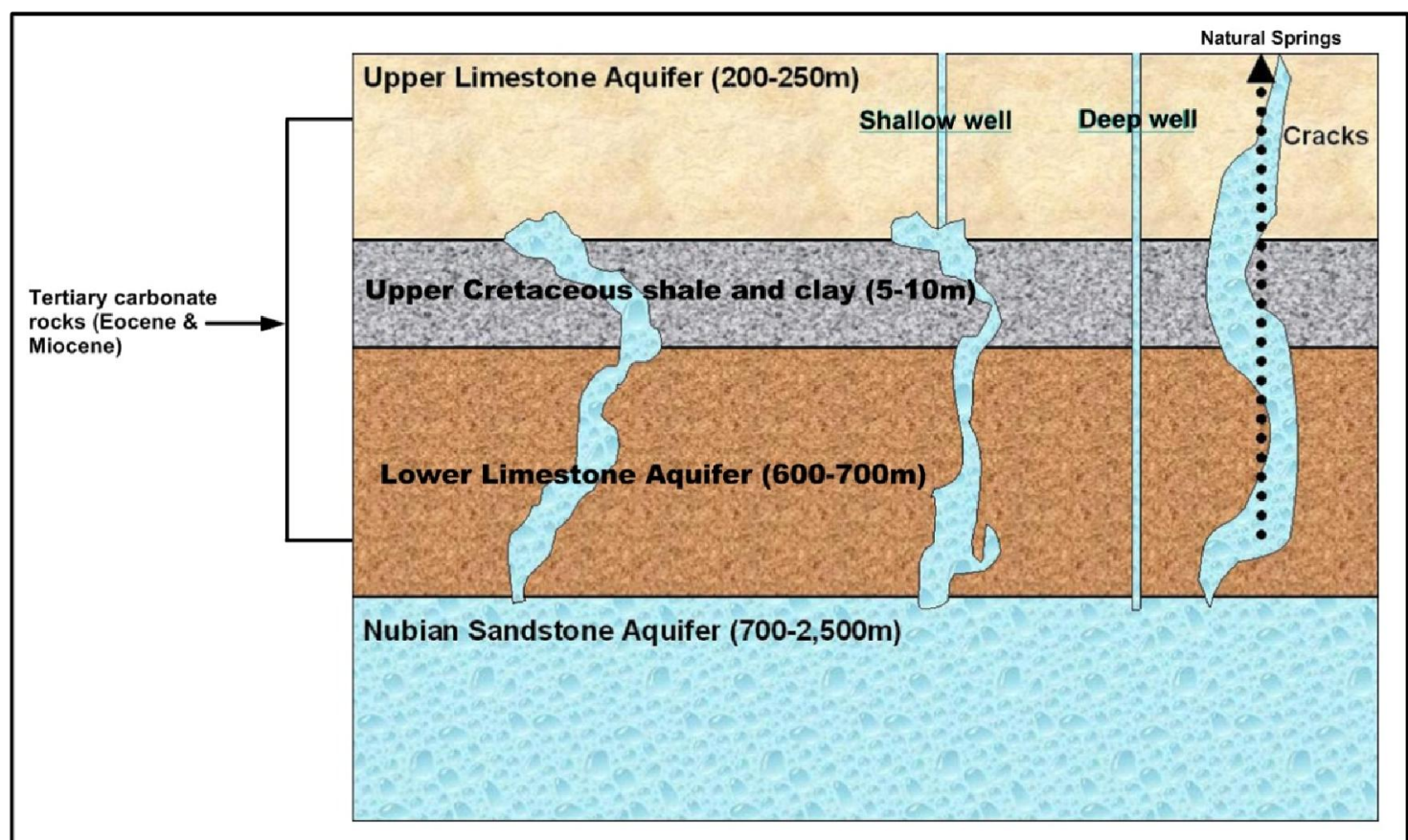

Fig. 8: Sketch diagram showing recharge and discharge of limestone groundwater aquifer system in Siwa Oasis (After Aly, 2015)

\section{Results and Discussion}

\section{Hydrochemical characterization}

The chemical composition of groundwater is determined by cation exchanges with the surrounding geological layers, dissolution and precipitation of minerals, and evaporation and oxidation-reduction reactions. Understanding these complicated hydrogeochemical processes will help to get an insight in the contribution of rock-water interactions that influence groundwater quality (Aly et al., 2016). These geochemical processes are responsible for the spatial and temporal variations of the groundwater's chemistry (Kumar et al., 2006). In addition, geochemical patterns (major ions and trace elements content) of groundwater largely determine its suitability for drinking, domestic, or agricultural purposes. The hydrochemical characters of any water body could be changed due to the effects of natural and man-made activities. As the groundwater in the study area is under confining conditions, the natural processes are expected to be the only responsible processes for groundwater modifications. This situation will be changed for the surface water of lakes acting as natural discharge areas, both the natural and human activities share in constituting the chemical properties of such water (El Sayed et al., 2017). 


\section{Water Salinity}

Different methods are used for water classification corresponding to its salinity values, among them Chebotarev's classification (1955). According to this classification, the natural water is classified into three main categories of total salinity; fresh water (TDS $<1500 \mathrm{mg} / \mathrm{l})$, brackish water (1500 to $5000 \mathrm{mg} / \mathrm{l}$ ) and saline water (TDS $>5000 \mathrm{mg} / \mathrm{l}$ ).

According to Chebotarev's classification (1955) and as in the table (2), the lakes water samples are highly saline water, where they have a total dissolved solids range from $15471-146118 \mathrm{mg} / 1$, this is due to the evaporation processes. Also, the drains water samples have salinity ranges from brackish to saline water, where they have salinity varies from $2801-8452 \mathrm{mg} / \mathrm{l}$, this is due to the human and agricultural activities. In addition, the springs water samples have salinity ranges from $169-6390 \mathrm{mg} / \mathrm{l}$ due to the human activities.

Table 2: The major constituent concentrations of the surface water and groundwater samples in Siwa area

\begin{tabular}{|c|c|c|c|c|c|c|c|c|c|c|c|c|}
\hline $\begin{array}{l}\text { Sample } \\
\text { No. }\end{array}$ & pH & $\mathbf{E C}$ & TDS & $\mathrm{Ca}^{2+}$ & $\mathrm{Mg}^{2+}$ & $\mathbf{N a}^{+}$ & $\mathbf{K}^{+}$ & $\mathrm{HCO}_{3}^{-}$ & $\mathrm{CO}_{3}{ }^{3-}$ & $\mathrm{SO}_{4}{ }^{2-}$ & $\mathrm{Cl}^{-}$ & $\mathrm{SiO}_{2}$ \\
\hline \multicolumn{13}{|c|}{ Surface water } \\
\hline \multicolumn{13}{|c|}{ Lakes } \\
\hline 1 & 7.80 & 228309 & 146118 & 10435 & 8452 & 30000 & 2750 & 245.13 & 25.38 & 2400 & 91933 & 33 \\
\hline 2 & 7.64 & 240527 & 153937 & 7826.1 & 5283 & 43000 & 1500 & 275.2 & 12.69 & 1000 & 95177 & 21 \\
\hline 3 & 7.86 & 24172 & 15471 & 1043.5 & 845.2 & 8800 & 8 & 301.04 & 8.46 & 3100 & 1515 & 30 \\
\hline \multicolumn{13}{|c|}{ Drains } \\
\hline 4 & 7.47 & 15640 & 8452 & 892 & 256 & 1810 & 104 & 219.6 & 4.5 & 1336 & 3940 & 2 \\
\hline 5 & 7.85 & 15004 & 8083 & 904 & 264 & 1648 & 96 & 160 & 0.00 & 1268 & 3822.8 & 2 \\
\hline 6 & 7.79 & 4910 & 2801 & 443.6 & 50 & 390 & 26 & 183 & 13.5 & 1162 & 624.8 & 1 \\
\hline 7 & 7.71 & 10590 & 5791 & 496 & 396 & 1038 & 80 & 247.05 & 13.5 & 852 & 2792 & 2 \\
\hline \multicolumn{13}{|c|}{ Springs } \\
\hline 8 & 8.00 & 4450 & 2399 & 121.74 & 95.09 & 600 & 33 & 180.62 & 16.92 & 360 & 1081.6 & 60 \\
\hline 9 & 8.04 & 5900 & 3276 & 139.13 & 158.48 & 860 & 36 & 206.4 & 8.46 & 240 & 1730.5 & 17 \\
\hline 10 & 7.92 & 8000 & 4587 & 208.7 & 190.17 & 1250 & 46 & 163.42 & 16.92 & 360 & 2433.6 & 25 \\
\hline 11 & 8.08 & 10760 & 6390 & 313.04 & 274.7 & 1650 & 87 & 215.03 & 12.69 & 700 & 3244.7 & 19 \\
\hline 12 & 8.13 & 9800 & 5369 & 243.5 & 243 & 1350 & 58 & 206.4 & 16.92 & 650 & 2703.9 & 20 \\
\hline 13 & 8.00 & 5400 & 3126 & 173.91 & 105.65 & 840 & 25 & 180.6 & 8.46 & 260 & 1622.34 & 35 \\
\hline 14 & 8.31 & 323 & 169 & 8.69 & 21.13 & 21 & 10 & 133.32 & 0 & 20 & 21.63 & 19 \\
\hline \multicolumn{13}{|c|}{ Groundwater } \\
\hline \multicolumn{13}{|c|}{ Miocene aquifer } \\
\hline 15 & 7.92 & 4160 & 2380 & 121.74 & 84.52 & 600 & 33 & 180.62 & 8.46 & 360 & 1081.6 & 27 \\
\hline 16 & 8.02 & 4310 & 2184 & 121.74 & 95.09 & 540 & 38 & 197.8 & 8.46 & 200 & 1081.6 & 41 \\
\hline 17 & 8.16 & 4810 & 2481 & 121.74 & 116.22 & 600 & 36 & 193.52 & 16.92 & 260 & 1232.98 & 23 \\
\hline 18 & 7.88 & 4390 & 2463 & 113.04 & 110.93 & 620 & 32 & 202.12 & 12.69 & 240 & 1232.98 & 27 \\
\hline 19 & 7.98 & 5690 & 3252 & 173.91 & 105.65 & 860 & 41 & 176.3 & 12.69 & 250 & 1622.34 & 18 \\
\hline 20 & 8.23 & 5540 & 3191 & 173.91 & 116.22 & 840 & 43 & 189.22 & 12.69 & 180 & 1730.5 & 2 \\
\hline 21 & 8.04 & 7600 & 4311 & 243.5 & 169.04 & 1100 & 39 & 193.52 & 8.46 & 275 & 2379.4 & 21 \\
\hline 22 & 8.11 & 5100 & 2909 & 139.13 & 212.68 & 640 & 28 & 189.2 & 8.46 & 380 & 1406 & 1 \\
\hline 23 & 7.27 & 9950 & 4965 & 260.9 & 190.17 & 1300 & 71 & 111.81 & 0 & 112.5 & 2974.3 & 8 \\
\hline 24 & 8.22 & 2800 & 1619 & 97.39 & 63.39 & 410 & 17 & 172 & 8.46 & 180 & 757.1 & 20 \\
\hline 25 & 8.15 & 3320 & 1891 & 113.04 & 73.96 & 470 & 38 & 189.22 & 8.46 & 120 & 973.4 & 20 \\
\hline 26 & 8.21 & 1916 & 1091 & 86.96 & 63.39 & 220 & 14 & 172 & 8.46 & 180 & 432.6 & 22 \\
\hline 27 & 8.17 & 4200 & 2379 & 95.65 & 95.09 & 620 & 50 & 223.6 & 16.92 & 200 & 1189.7 & 28 \\
\hline 28 & 8.01 & 6600 & 3750 & 191.3 & 158.48 & 950 & 32 & 206.4 & 8.46 & 360 & 1946.8 & 30 \\
\hline 29 & 8.06 & 4200 & 2368 & 121.74 & 105.65 & 580 & 20 & 172.02 & 12.69 & 360 & 1081.6 & 22 \\
\hline 30 & 7.95 & 4300 & 2312 & 121.74 & 105.65 & 580 & 20 & 172.02 & 8.46 & 200 & 1189.72 & 19 \\
\hline 31 & 8.03 & 4300 & 2317 & 121.74 & 105.65 & 580 & 21 & 180.6 & 8.46 & 200 & 1189.72 & 8 \\
\hline 32 & 8.18 & 2600 & 1458 & 121.74 & 79.24 & 300 & 14 & 172.02 & 8.46 & 200 & 648.94 & 28 \\
\hline 33 & 8.14 & 6900 & 3888 & 243.5 & 169.04 & 950 & 33 & 193.52 & 12.69 & 220 & 2163.12 & 25 \\
\hline \multicolumn{13}{|c|}{ Nubian sandstone aquifer } \\
\hline 34 & 8.20 & 500 & 255 & 17.39 & 31.69 & 30 & 10 & 189.22 & 8.46 & 20 & 43.26 & 22 \\
\hline 35 & 8.24 & 542 & 295 & 26.09 & 26.41 & 34 & 21 & 193.52 & 8.46 & 39.5 & 43.26 & 20 \\
\hline 36 & 7.90 & 430 & 250 & 17.4 & 21.13 & 36 & 15 & 137.62 & 16.92 & 36 & 38.94 & 21 \\
\hline 37 & 8.21 & 320 & 169 & 8.69 & 21.13 & 22 & 9 & 133.32 & 0 & 20 & 21.63 & 27 \\
\hline
\end{tabular}


On the other hand, the Miocene aquifer groundwater samples have a total dissolved solids range from $1091 \mathrm{mg} / \mathrm{l}$ to $4965 \mathrm{mg} / \mathrm{l}$, with a mean value of $2659 \mathrm{mg} / \mathrm{l}$. The majority of the Miocene groundwater samples in the study area (89\%) have salinity ranges from 1619 to $4965 \mathrm{mg} / 1$ (brackish water), while $11 \%$ of the total groundwater samples have salinity ranges from 1091 to $1458 \mathrm{mg} / 1$ (fresh water). On the other hand, the selected Nubian sandstone groundwater samples in the study area are fresh water, where they have salinity varies from $169-295 \mathrm{mg} / 1$.

The higher salinity in water abstracted from the Miocene aquifer (mean value $2659 \mathrm{mg} /$ l) compared to that reported in the Nubian sandstone aquifer (mean value $242 \mathrm{mg} / \mathrm{l}$ ) is due to the leaching and dissolution processes of carbonate salts that occurred through passing the groundwater across the Eocene sediments where the salinity dramatically increases. This is confirmed with El Hossary (1999) who stated that the salinity increases due to the dominant local recharge to the carbonate aquifer via the upward leakage from the Nubian Sandstone aquifer through fault plains and the developed fracture system, i.e., this is due to the water-rock (halite) interaction during the deep fresh water flows upward from the Nubian Sandstone aquifer to the fractured carbonate zones through the fault planes (Fig.8).

Also, the high salinity of the Miocene groundwater indicates that the Miocene aquifer system still contains relict of marine water, or such type of water is a property of a marine environment and evaporite sequences. The increase in such constituents in Siwa Oasis may reflect the extensive exist of the marine and evaporite deposits that changes laterally and vertically.

Generally, the occurrence of brackish groundwater in Siwa Oasis may be due to the stagnation of the groundwater due to the well abandonment, the shallow depth of the wells which activates the role of evaporation and hence, the concentration of salts, the scarcity of rainfall $(45 \mathrm{~mm} /$ year $)$ which is considered the main source of the aquifer recharge, the marine origin of the exposed leached sediments dominating the recharge area which are mostly composed of limestone and shale.

While the low water salinity of some Miocene groundwater samples in the study area is due to the effect of the recharge or mix with Nubian sandstone groundwater, this can be emphasized by El Hossary (1999) who stated that, the contradicting age dating and wide range of ages reported to groundwater from the Nubian aquifer lead to consider appreciable recharge or at least mix with water from the fluvial environment dominated at the Post-Miocene time in Egypt. This explains the presence of good quality parts of the carbonate aquifer and notable signs of water erosions in carbonates and other surface units such as old channels, dry gorges, and cavities along Siwa-Matruh road.

Noteworthy to mention that, the carbonate aquifer system in the study area is predominantly hard limestone with chalky limestone in some localities, then this change in the aquifer facies may lead to a possible change in the water quality while passing through it.

In brief, the increase in the TDS and major ion composition as well as the change in metal constituents in the Miocene groundwater, compared to that groundwater of the Nubian sandstone aquifer, could be attributed to the influence of geologic formations through which the groundwater has flowed.

The salinity of the Miocene groundwater in the study area increases in two directions, the northwestern and north directions, i.e., in the same direction of the groundwater flow (NWN), Fig.9.

\section{The assemblages of hypothetical salts combinations}

Hypothetically, the ions of the strong acids $\left(\mathrm{Cl}^{-}\right.$and $\left.\mathrm{SO}_{4}{ }^{2-}\right)$ form chemical combinations with alkalis $\left(\mathrm{Na}^{+}+\mathrm{K}^{+}\right)$and the rest of the acid radical's combine with the alkaline earth's $\left(\mathrm{Ca}^{2+}\right.$ and $\left.\mathrm{Mg}^{2+}\right)$. If the cations of alkalis and alkaline earth's are in surplus in the water, they will combine with the weak acids $\left(\mathrm{CO}_{3}{ }^{2-}\right.$ and $\left.\mathrm{HCO}_{3}{ }^{-}\right)$. The combination between major anions and cations reveals the formation of different two groups of hypothetical salts combinations for both the studied drains and springs individually as well as three and two groups of hypothetical salts combinations for both the Miocene and Nubian sandstone aquifers, respectively (Table 3 and Fig.10).

The majority of the studied drains water samples (75\%) were characterized by the assemblage (V), regardless of their total salinities. This salts assemblage (V) contains two chloride salts $\left(\mathrm{MgCl}_{2}\right.$ and $\mathrm{CaCl}_{2}$ ) reflect the effect of leaching and dissolution processes of the marine deposits that consisting the cultivated soil in the study area. While, the rest of the drains water samples $(25 \%)$ were characterized by the assemblage (III), regardless of their total salinities. This salts assemblage (III) contains three sulfate salts $\left(\mathrm{Na}_{2} \mathrm{SO}_{4}, \mathrm{MgSO}_{4}\right.$ and $\left.\mathrm{CaSO}_{4}\right)$, this excess of $\mathrm{SO}_{4}{ }^{2-}$ concentration can be attributed to fertilizers and insecticides used in the surrounding farmlands, in addition to leaching of salts from soil 
close to the sulfate rich desert zone as well as due to the anthropogenic activities as discharge of wastewater disposal.

Also, the majority of the studied springs water samples (86\%) were characterized by the assemblage (IV), regardless of their total salinities. This salts assemblage (IV) contains two sulfate salts $\left(\mathrm{MgSO}_{4}\right.$ and $\left.\mathrm{CaSO}_{4}\right)$ reflect the anthropogenic activities due to the use of the springs as swimming pools for humans. While, the rest of the springs water samples (14\%) were characterized by the assemblage (I), regardless of their total salinities. This salts assemblage (I) contains two carbonate salts $\mathrm{NaHCO}_{3}$ and $\left.\mathrm{Mg}\left(\mathrm{HCO}_{3}\right)_{2}\right\}$, this reflects that the spring water comes originally from the Nubian sandstone aquifer.

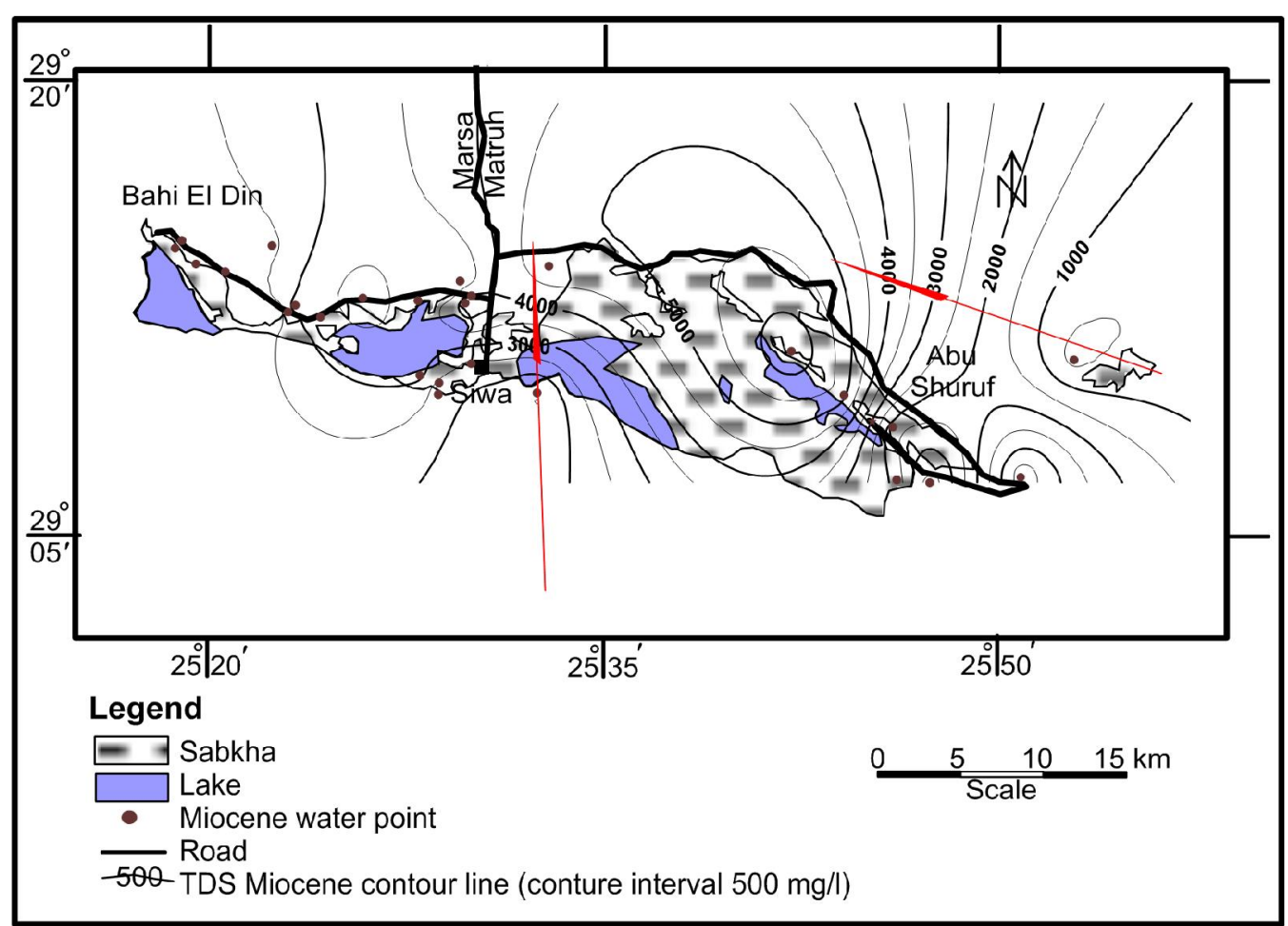

Fig. 9: The Miocene groundwater salinity contour map in Siwa Oasis

Table 3: The hypothetical salts combinations of the surface water (lakes, drains and springs) and groundwater (Miocene and Nubia aquifers) samples in the study area

\begin{tabular}{|c|c|c|}
\hline Assemblages & Hypothetical salts combinations & Percentage \\
\hline \multicolumn{3}{|c|}{ Surface water } \\
\hline \multicolumn{3}{|c|}{ Lakes water samples } \\
\hline IV & $\mathrm{NaCl}, \mathrm{MgCl}_{2}, \mathrm{MgSO}_{4}, \mathrm{CaSO}_{4}$ and $\mathrm{Ca}\left(\mathrm{HCO}_{3}\right)_{2}$ & $33 \%$ \\
\hline $\mathrm{V}$ & $\mathrm{NaCl}, \mathrm{MgCl}_{2}, \mathrm{CaCl}_{2}, \mathrm{CaSO}_{4}$ and $\mathrm{Ca}\left(\mathrm{HCO}_{3}\right)_{2}$ & $67 \%$ \\
\hline \multicolumn{3}{|c|}{ Drains water samples } \\
\hline III & $\mathrm{NaCl}, \mathrm{Na}_{2} \mathrm{SO}_{4}, \mathrm{MgSO}_{4}, \mathrm{CaSO}_{4}$ and $\mathrm{Ca}\left(\mathrm{HCO}_{3}\right)_{2}$ & $25 \%$ \\
\hline $\mathrm{V}$ & $\mathrm{NaCl}, \mathrm{MgCl}_{2}, \mathrm{CaCl}_{2}, \mathrm{CaSO}_{4}$ and $\mathrm{Ca}\left(\mathrm{HCO}_{3}\right)_{2}$ & $75 \%$ \\
\hline \multicolumn{3}{|c|}{$\begin{array}{l}\text { Springs water samples } \\
\end{array}$} \\
\hline I & $\mathrm{NaCl}, \mathrm{Na}_{2} \mathrm{SO}_{4}, \mathrm{NaHCO}_{3}, \mathrm{Mg}\left(\mathrm{HCO}_{3}\right)_{2}$ and $\mathrm{Ca}\left(\mathrm{HCO}_{3}\right)_{2}$ & $14 \%$ \\
\hline IV & $\mathrm{NaCl}, \mathrm{MgCl}_{2}, \mathrm{MgSO}_{4}, \mathrm{CaSO}_{4}$ and $\mathrm{Ca}\left(\mathrm{HCO}_{3}\right)_{2}$ & $86 \%$ \\
\hline \multicolumn{3}{|c|}{$\begin{array}{c}\text { Groundwater } \\
\text { Miocene aquifer }\end{array}$} \\
\hline II & $\mathrm{NaCl}, \mathrm{Na}_{2} \mathrm{SO}_{4}, \mathrm{MgSO}_{4}, \mathrm{Mg}\left(\mathrm{HCO}_{3}\right)_{2}$ and $\mathrm{Ca}\left(\mathrm{HCO}_{3}\right)_{2}$ & $5 \%$ \\
\hline IV & $\mathrm{NaCl}, \mathrm{MgCl}_{2}, \mathrm{MgSO}_{4}, \mathrm{CaSO}_{4}$ and $\mathrm{Ca}\left(\mathrm{HCO}_{3}\right)_{2}$ & $74 \%$ \\
\hline $\mathrm{V}$ & $\mathrm{NaCl}, \mathrm{MgCl}_{2}, \mathrm{CaCl}_{2}, \mathrm{CaSO}_{4}$ and $\mathrm{Ca}\left(\mathrm{HCO}_{3}\right)_{2}$ & $21 \%$ \\
\hline \multicolumn{3}{|c|}{ Nubia sandstone aquifer } \\
\hline I & $\mathrm{NaCl}, \mathrm{Na}_{2} \mathrm{SO}_{4}, \mathrm{NaHCO}_{3}, \mathrm{Mg}\left(\mathrm{HCO}_{3}\right)_{2}$ and $\mathrm{Ca}\left(\mathrm{HCO}_{3}\right)_{2}$ & $50 \%$ \\
\hline II & $\mathrm{NaCl}, \mathrm{Na}_{2} \mathrm{SO}_{4}, \mathrm{MgSO}_{4}, \mathrm{Mg}\left(\mathrm{HCO}_{3}\right)_{2}$ and $\mathrm{Ca}\left(\mathrm{HCO}_{3}\right)_{2}$ & $50 \%$ \\
\hline
\end{tabular}




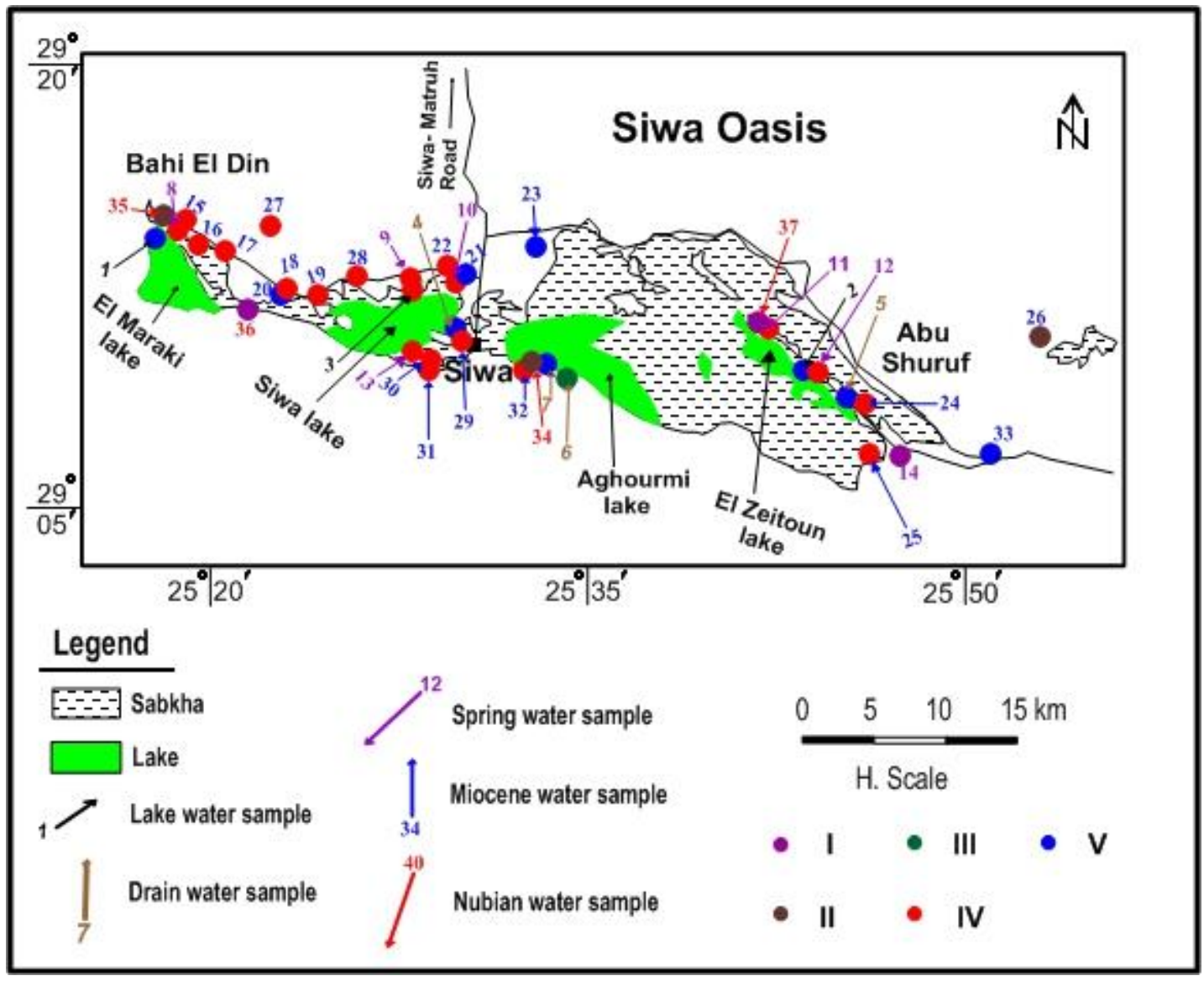

Fig.10: The hypothetical salts assemblages distribution map of the water resources in Siwa Oasis

On the other hand, the majority of the Miocene groundwater samples in the study area (79\%) were characterized by the assemblages (II and IV), regardless of their total salinities. These salts assemblages (II and IV) contain three sulfate salts $\left(\mathrm{Na}_{2} \mathrm{SO}_{4}, \mathrm{MgSO}_{4}\right.$ and $\left.\mathrm{CaSO}_{4}\right)$. The increase of sulfate content may be due to the dissolution of gypsum mineral $\mathrm{CaSO}_{4} \cdot 2 \mathrm{H}_{2} \mathrm{O}$ included in the water-bearing strata in addition to the sulfate salts characterize groundwater affected by evaporating deposits. Also, exceeded $\mathrm{SO}_{4}{ }^{2-}$ concentration can be attributed to seepage from both drains and springs water to the Miocene groundwater during the fracture system, in addition to the penetrated irrigation water from the agricultural lands that can also contribute sulfates to groundwater from agrochemicals or decay of plant residues or fertilizers and insecticides used in the surrounding farmlands (return flow after irrigation). While, the rest of the Miocene groundwater samples $(21 \%)$ in the study area were characterized by the assemblage $(\mathrm{V})$, regardless of their total salinities. This salts assemblage $(\mathrm{V})$ contains two chloride salts $\left(\mathrm{MgCl}_{2}\right.$ and $\left.\mathrm{CaCl}_{2}\right)$ reflect the effect of marine salts combinations (marine facies groundwater) from the aquifer matrices, i.e., the effect of leaching and dissolution processes of the marine deposits of the strata.

It is worth noting that, the Nubian sandstone groundwater samples in the study area were characterized by the assemblages salts (I and II), regardless of their total salinities. These salts assemblages (I and II) contain two carbonate salts $\left\{\mathrm{NaHCO}_{3}\right.$ and $\left.\mathrm{Mg}\left(\mathrm{HCO}_{3}\right)_{2}\right\}$ and two sulfate salts $\left(\mathrm{MgSO}_{4}\right.$ and $\left.\mathrm{CaSO}_{4}\right)$ reflect the meteoric water origin of the Nubian sandstone groundwater, in addition reflects the effect of the leaching and dissolution processes of the terrestrial salts (mteoric water) or the continental depositional environment of the Nubian sandstone aquifer.

Assemblage (II) represents an earlier stage of chemical development than that of assemblages (IV and V). Also, assemblage II (two bicarbonate salts) reflects the recharge effect of the Nubian sandstone groundwater on the Miocene groundwater, while the assemblages (IV and V) characterize groundwater affected by the leaching and the dissolution of the marine deposits. The presence of the hypothetical 
salts assemblage (II) in both the Nubian sandstone groundwater and Miocene groundwater indicates that there is a hydraulic connection between the two aquifers in the study area.

There is a progress in the chemical development is noticed in the groundwater that dominated by the assemblage II (earlier and less stages of chemical development, where two bicarbonate salts $\left\{\mathrm{Mg}\left(\mathrm{HCO}_{3}\right)_{2}\right.$ and $\left.\mathrm{Ca}\left(\mathrm{HCO}_{3}\right)_{2}\right\}$ are recognized to the groundwater that dominated by the assemblages (IV and V, transitional and more advanced stages of chemical development, where two sulfate salts $\left\{\mathrm{MgSO}_{4}\right.$ and $\left.\mathrm{CaSO}_{4}\right\}$ and two chloride salts $\left\{\mathrm{MgCl}_{2}\right.$ and $\left.\mathrm{CaCl}_{2}\right\}$, respectively, are found). The assemblage IV is considered as a transitional stage between continental and marine facies of groundwater II and V, respectively. This indicates meteoric water origin (groundwater comes from the Nubian sandstone aquifer) influenced by leaching of marine salts in the Miocene aquifer. In conclusion, the groundwater of the Miocene aquifer is chemically, in the less and middle stages as well as more stage of evolution as its groundwater is a mixture of the two sources (meteoric water of the Nubian sandstone aquifer and marine water of the Miocene aquifer). i.e., the Miocene aquifer is recharged directly from the Nubian sandstone aquifer (due to the direct hydraulic connection through faulting), where alternatively, the groundwater head in the carbonate aquifer varies in average between 50 and $60 \mathrm{~m}$ (a.m.s.l.) that shows a considerable difference to the pressure head in the Nubian sandstone aquifer. Such a hydrologic setting favors a dominant local recharge to the carbonate aquifer via the upward leakage from the Nubian sandstone aquifer through fault plains and the developed fracture system.

It showed that the assemblages (IV and V) which contain the hypothetical salts $\mathrm{MgCl}_{2}, \mathrm{CaCl}_{2}$, $\mathrm{MgSO}_{4}$ and $\mathrm{CaSO}_{4}$ were distributed all over the study area (Fig.10), this means that there are great similarities of the hydrochemical composition between both the drains and springs water as well as the Miocene groundwater which may reflect the same geochemical environment where the water is discharged. Otherwise, the springs, under study, discharge their water through faults cutting in the carbonate aquifers. Also, this indicates that there is seepage or infiltration from drains and springs water to the Miocene groundwater during the limestone fracture.

\section{Geochemical classification}

As groundwater moves along flow lines from recharge to discharge areas, its chemistry is altered by the effects of a variety of geochemical processes. Different authors have proposed methods for the geochemical classification of groundwater; from these methods is the trilinear plotting system (Piper's, 1953), that is used in the present study as a useful tool for investigating the water quality of the Miocene groundwater where it is based on the concentrations of both the anions and cations.

By plotting the chemical data of the studied drains and springs water samples (surface water) as well as the Miocene and Nubian sandstone groundwater samples in the study area on Piper trilinear diagram (Fig.11), it is remarkable that; half of the drains water samples in the study area are located in sub-area 6 , where secondary salinity exceeds $50 \%$, while the other half of the samples are located in sub-area 7 , where primary salinity exceeds $50 \%$, that is, chemical properties of the water are dominated by alkalies and strong acids.

Also, it is shown that; the majority of the springs water samples $(86 \%)$ are located in sub-area 7 , while the rest of the samples (14\%) are located in sub-area 5, where secondary salinity exceeds $50 \%$, that is, chemical properties of the water are dominated by alkaline earths and weak acids (Fig.11).

On the other hand, it was noticed that; the majority of the Miocene groundwater samples $(90 \%)$ are located in sub-area 7, while the rest of the groundwater samples $(10 \%)$ are located in sub-area 5 (Fig.11). This means that, the marine salts of the carbonate matrix of this aquifer and other sources of recharge have its contribution to the nature and composition of groundwater to its plotting in sub-area $7(90 \%)$ and sub-area $5(50 \%)$. So, Piper trilinear diagram suggests that the groundwater of the Miocene aquifer in the study area is of meteoric origin of mineralization, where the main source of recharge is the Nubian sandstone aquifer. This stands in agreement with the hypothetical salts combinations in the Miocene groundwater (II, IV and V).

In addition, all studied Nubian sandstone groundwater samples are located in sub-area 5 (Fig.11). This means that, the groundwater is dominated by alkaline earths and weak acids, mostly produced occasionally by continental sediments dominating their chemical composition. So, the Piper trilinear diagram suggests that, the groundwater of the Nubian sandstone aquifer is of meteoric origin of mineralization, where infiltrated rain water is affected by leaching and the dissolution of terrestrial salts. 
This stands in agreement with the hypothetical salts combinations in the Nubian sandstone groundwater (I and II).

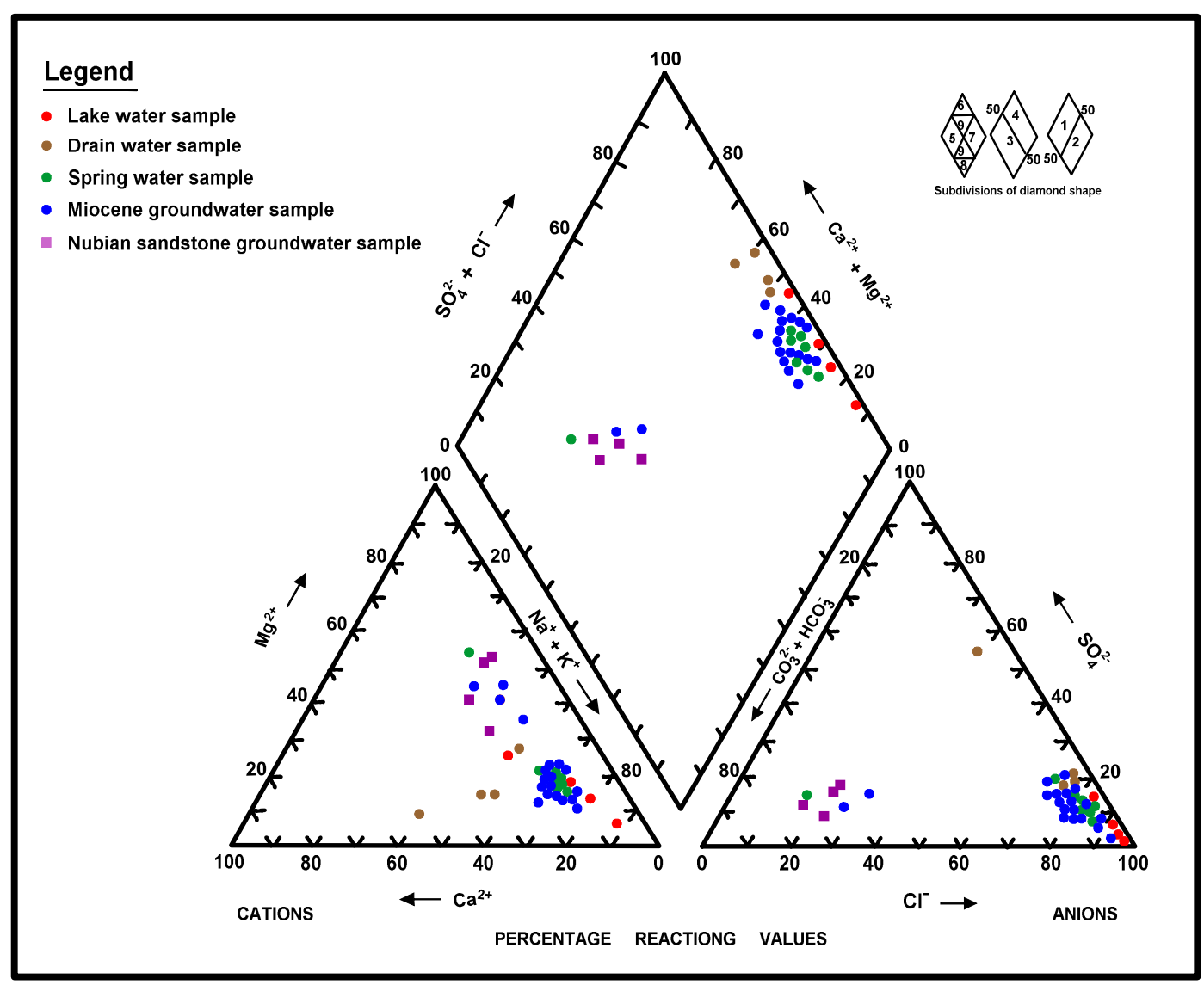

Fig. 11: Piper trilinear diagram showing the major ionic composition of the studied water samples in Siwa Oasis

It was shown that, the drains and springs water samples are allocated around the Miocene groundwater samples in sub-area 7 (Fig.11), which indicates that there are seeping from the drains and springs water to the Miocene groundwater. Also, the Nubian sandstone groundwater samples are allocated around the Miocene groundwater samples in sub-area 5 (Fig.11), which indicates that there is a hydraulic connection between the concerned two aquifers. In addition to, the presence of springs water samples around the Nubian sandstone groundwater samples in sub-area 5 (Fig.11), indicates that the water of springs in the study area are coming from the Nubian sandstone aquifer.

In other words, the dominant cations in both Miocene and Nubian sandstone groundwater at Siwa Oases were sodium and then magnesium. While, the dominant anions in the Miocene groundwater at Siwa Oases was chloride, this means that there is water-halite interaction during upward fresh water flows from the Nubian sandstone aquifer to the Miocene aquifer through the fault planes.

Noteworthy to mention that, these obtained results are standing in agreement with the hypothetical salts in both the drains water (III and V) and springs water (I and IV) as well as the Miocene groundwater (II, IV and V), which indicates that there are similarity of chemical composition between both the drains and springs water and the groundwater of the Miocene aquifer. This confirmed that there is seepage from both the drains and springs water to the Miocene groundwater.

\section{Water pollution}

Water pollution is the contamination of water bodies that usually as a result of human activities. Where, water bodies in the study area include drains, springs and groundwater. Water pollution results 
when contaminants are introduced into the natural environment, as the releasing of waste water into natural water bodies that can lead to degradation of aquatic ecosystems. In turn, this can lead to public health problems for people, where water pollution is the leading worldwide cause of disease and death. Noteworthy, all plants and organisms living in or being exposed to polluted water bodies can be impacted.

Water pollution can be classified as surface water or groundwater pollution and the interactions between groundwater and surface water is complex, where surface water seeps through the soil till reach to groundwater. Causes of groundwater pollution include; chemicals, sewage, fertilizers, pesticide, commercial and industrial leaks, hydraulic fracturing and landfill leachate. Where, contaminant transport is facilitated by a high permeability of the aquifer formations.

In order to assess the actual groundwater quality of the Miocene aquifer and to understand the influence of the factors generating the pollution, both the hydrochemistry (trace elements and minor constituents) and microbiology (total coliform counts and total colony counts) are playing essential roles.

\section{Contamination hazards}

The contamination hazards are concentrated in the agricultural and settlement areas, which includes a wide range of inorganic pollutants (trace elements) such as, Mn, Fe and $\mathrm{Zn}$ (Table 4).

As in table (4), it was found that $100 \%$ and $60 \%$ of the drains and springs water samples, respectively, have slight concentrations of manganese, iron and zinc, this is due to the aeration and oxidation process of trace elements in the drains and springs surface area that is expected as follow;

$$
4 \mathrm{Fe}^{2+} \text { (soluble) }+3 \mathrm{O}_{2} \rightarrow 2 \mathrm{Fe}_{2} \mathrm{O}_{3} \text { (precipitate) }
$$

On the other hand, the rest of the springs water samples (40\%) are polluted as they have iron concentrations ranging between 1.068 and $1.701 \mathrm{mg} / \mathrm{l}$, this is due to that the water of springs comes from the Nubian sandstone aquifer that rich with concentrations of iron.

Noteworthy mentioning that, half of the Miocene groundwater samples are polluted as they have manganese, iron and zinc concentrations more than the permissible limits of drinking, 0.4, 0.3 and $0.05 \mathrm{mg} / 1$, respectively, according to $\mathrm{WHO}$ (2011). Also, all the Nubian sandstone groundwater samples have iron and zinc concentrations more than the permissible limits, respectively (Table 4). This confirmed that there is a hydraulic connection between the two aquifers (Miocene and the Nubian sandstone aquifers) in the study area.

It was found that, the zinc concentration was low in general; however, the iron concentration was the highest trace elements in the Miocene groundwater in the study area followed by manganese (Table 4 ), this is due to the ferruginous mineralization in the rock-water interface may take place. Where, the high concentration of iron in groundwater causes kidney faliure.

In other words, according to FAO (1985), the majority of surface and groundwater samples in the study area have manganese, iron and zinc concentrations are within the safe and acceptable levels for irrigation, $0.2,5$ and $2 \mathrm{mg} / \mathrm{l}$, respectively, except the groundwater samples Nos. 23 and 27 which contain manganese and iron concentrations more than the permissible limits for irrigation.

\section{Land use activities}

Possible contaminants include minor constituents as phosphate and nitrate that may originate from untreated domestic wastewaters, various agricultural activities and waste dumping.

Phosphates are not toxic to people or animals unless they are present in very high levels. Digestive problems could occur from extremely high levels of phosphate. Phosphate itself does not have notable adverse health effects. However, phosphate levels greater than 1.0 (Kotoski, 1997) may interfere with coagulation in water treatment plants. It is noticed that, the majority of the studied water samples in the investigated area have phosphate concentrations less than $1 \mathrm{mg} / 1$.

High level of nitrate in drinking water is due to excessive use of agricultural fertilizers, decayed vegetable water, domestic effluent, sewage disposal industrial discharges, leachable from refuse dumps. The excess concentration of nitrate causes disease, where Methemoglobinemia oxygen transport depends on the maintenance of intracellular hemoglobin in the reduced $\left(\mathrm{Fe}^{2+}\right)$ state. When hemoglobin is oxidized to methemoglobin, the heme iron becomes $\left(\mathrm{Fe}^{3+}\right)$ is incapable of binding oxygen. Methemoglobinemia is suspected in any cyanotic patient. Nitrites also react directly with hemoglobin in human blood and other warm-blooded animals to produce methemoglobin. Methemoglobin destroys 
the ability of red blood cell to transport oxygen. This condition is especially serious in babies under three months of age.

Table 4: The trace and minor constituents in the surface water and groundwater samples in Siwa area

\begin{tabular}{|c|c|c|c|c|c|c|}
\hline Sample No. & Sample Name & Mn & $\mathbf{F e}$ & Zn & $\mathrm{PO}_{4}{ }^{3-}$ & $\mathrm{NO}_{3}^{-}$ \\
\hline \multicolumn{7}{|c|}{ Surface water } \\
\hline \multicolumn{7}{|c|}{ Lakes } \\
\hline 1 & EI Maraki Lake & 0.081 & 0.315 & 0.017 & 0.3 & 3 \\
\hline 2 & El Zeitoun Lake & 0.182 & 1.61 & 0.149 & 0.3 & 6.6 \\
\hline 3 & Siwa Lake & 0.032 & 0.483 & 0.046 & 0.4 & 19.6 \\
\hline \multicolumn{7}{|c|}{ Drains } \\
\hline 4 & El Qarabeen EI Omumy Drain & 0.011 & 0.00 & 0.001 & 0.89 & 8.4 \\
\hline 5 & Omumy Drain & 0.005 & 0.00 & 0.003 & 0.816 & 9.8 \\
\hline 6 & Gheet EI Khalel Drain & 0.009 & 0.00 & 0.001 & 0.61 & 8.4 \\
\hline 7 & Loeab Ali Arafa Drain & 0.004 & 0.208 & 0.001 & 0.65 & 11.2 \\
\hline \multicolumn{7}{|c|}{ Springs } \\
\hline 8 & Ain Taghlia (Romani) & 0.061 & 0.094 & 0 & 0.5 & 14.4 \\
\hline 9 & Ain Telwa & 0.069 & 1.186 & 0.067 & 0.6 & 4.2 \\
\hline 10 & Ain Kharafala & 0.059 & 0.043 & 0.122 & 0.5 & 25.2 \\
\hline 11 & Ain Korisht & 0.041 & 1.068 & 0.096 & 0.9 & 5.4 \\
\hline 12 & Ain Abu Shrouf & 0.021 & 0 & 0 & 0.9 & 6 \\
\hline 13 & Ain Fentas & 0.054 & 0.089 & 0.066 & 0.4 & 2.6 \\
\hline 14 & Ain El Zahra & 0.129 & 1.701 & 0.052 & 2.2 & 5.8 \\
\hline \multicolumn{7}{|c|}{ Groundwater } \\
\hline \multicolumn{7}{|c|}{ Miocene aquifer } \\
\hline 15 & Sherif Senosy & 0.115 & 0.038 & 0 & 1.4 & 5.6 \\
\hline 16 & Abd EI Hamid EI Sarar & 0.092 & 0.026 & 0.003 & 0.5 & 8.4 \\
\hline 17 & Bahi EI Din & 0.04 & 0.082 & 0.005 & 0.6 & 16 \\
\hline 18 & Hasan Osman Saleh & 0.033 & 0.063 & 0.032 & 0.6 & 6 \\
\hline 19 & Rahmoon Well & 0.048 & 0.056 & 0.036 & 0.9 & 1.6 \\
\hline 20 & Bahreat Well & 0.043 & 0.565 & 0.075 & 0.9 & 16.4 \\
\hline 21 & Lotba Well & 0.069 & 0.187 & 0.005 & 1 & 10 \\
\hline 22 & Nagdeen Well & 0.072 & 0.363 & 0.081 & 1 & 15.4 \\
\hline 23 & Mohamed Omar Musa & 0.502 & 20.11 & 0 & 3.8 & 3 \\
\hline 24 & Abu Shrouf - El Zeitoun Well & 0.013 & 0.032 & 0.041 & 2.1 & 5.2 \\
\hline 25 & Abu Shrouf - El Mortazaq Well & 0.029 & 0.02 & 0.006 & 0.6 & 7 \\
\hline 26 & Siwa Well 1 & 0.028 & 1.775 & 0.013 & 0.4 & 5.2 \\
\hline 27 & Siwa Well 2 & 0.655 & 3.031 & 0.067 & 1.2 & 4.6 \\
\hline 28 & Mohamed Ibrahim MusIm & 0.027 & 0.011 & 0.063 & 0.6 & 16.6 \\
\hline 29 & Tekzerty Well 1 & 0.031 & 0.101 & 0.149 & 0.4 & 6.5 \\
\hline 30 & Tekzerty Well 2 & 0.059 & 0.083 & 0.195 & 0.5 & 3 \\
\hline 31 & El Shaheim Well & 0.094 & 3.234 & 0.03 & 1.2 & 4 \\
\hline 32 & EI Moulok Well & 0 & 0 & 0.127 & 0.6 & 34.8 \\
\hline 33 & Abu El Makarim Al Ansary Well & 0.001 & 0.163 & 0.102 & 0.9 & 1 \\
\hline \multicolumn{7}{|c|}{ Nubian sandstone aquifer } \\
\hline 34 & El Dakror Well & 0.09 & 1.018 & 0.116 & 0.6 & 16 \\
\hline 35 & Abd El Gabbar Well & 0.072 & 0.496 & 0.017 & 0.8 & 8.4 \\
\hline 36 & Ghazalat Well & 0.132 & 4.064 & 0.016 & 2.2 & 1 \\
\hline 37 & Korisht Well & 0.081 & 0.881 & 0.013 & 0.4 & 3 \\
\hline \multicolumn{2}{|c|}{ Permissible limits for drinking purposes } & 0.4 & 0.3 & 0.05 & ----- & 13 \\
\hline
\end{tabular}

Almost all studied water samples in the study area have nitrate concentrations lower than the WHO (2011) of 50mg/l dangerous for babies and smaller children (blue baby disease). While, Burkart and Kolpin (1993) and Eckhardt and Stackelberg (1995) stated that groundwater with $\mathrm{NO}_{3}{ }^{-}$concentration exceeding the threshold of $13 \mathrm{mg} / \mathrm{l}$ is considered contaminated due to human activities (the so-called human affected value). So, $38 \%$ of the Miocene groundwater samples are contaminated as they have $\mathrm{NO}_{3}{ }^{-}$concentrations more than the human affected value. 


\section{Microbiology and drinking water hygiene}

Possible contaminants include microbial pathogens, where the pathogen contamination may originate from untreated domestic waste waters and waste dumping.....etc. Qualitative and quantitative microbiological analysis of 29 water samples were collected from lakes, drains and springs as well as Miocene and Nubian groundwater at different localities in Siwa Oasis had been done and was shown in table (5).

The obtained results indicate that the total colony counts (total viable counts, TVC) of the selected water samples in the study area ranged from 123-191, 117-190, 77-240 and 84-204 cfu/ml (Table 5), for the drains, springs, Miocene aquifer and Nubian sandstone aquifer water samples, respectively. This indicates that all drains and springs water samples as well as the majority of the selected Miocene and Nubian sandstone groundwater samples have total colony counts (microbial load) were generally high, exceeding both the recommended limit of $1 \times 10^{2} \mathrm{cfu} / \mathrm{ml}$ for water (Okonko et al., 2008), and the recommended standard for water (nil) according to FAO (1997).

The most probable number (M.P.N.) for the total coliform counts of the selected water samples in the study area ranged from 24-67, 15-60, 7-52 and 15-46 M.P.N./100ml (Table 5), for the drains, springs, Miocene aquifer and Nubian sandstone aquifer water samples, respectively. This indicates that all drains and springs water samples as well as the majority of the selected Miocene and Nubian sandstone groundwater samples have total coliform counts were generally high, exceeding the recommended standard of water (less than 2M.P.N./100ml) according to FAO, 1997. Owing to that the total coliform counts of these water samples were grossly contaminated which may result from the presence of high levels of organic waste matter. Triple Sugar Iron (TSI) test recorded the presence of Escherichia coli (sewage pollution) in all contaminated water samples.

The influence of continuous sources of pollution, such as agricultural activities, sewage water, untreated drains water, illegal dumping of untreated domestic wastes, livestock management, faecal deposit, animal wastes, human excrement and return flow after irrigation as well as the reuse of drains water in agricultural irrigation to increase water resources in arid and semiarid regions leads to generation of microbiological contamination (faecal coliform bacterial concentrations) in most of the water resources samples (drains and springs as well as groundwater samples) in the study area. This can be confirmed by Okonko (2008) and Richman (1997) who concluded that the presence of coliforms group in most of these water samples generally suggests that a certain water samples may have been contaminated with faeces either of human or animal origin. Other more dangerous microorganisms could be present.

Coliform bacteria are a collection of relatively pathogenic microorganisms that live in large number in the intestines of the warm and cold blooded animals where they aid in the digestion of food. Specific subgroups of this collection are the fecal coliform bacteria, the most common member being Escherichia coli. These organisms may be repeated from the total coliform group by their ability to grow at elevated temperatures and are associated only with the fecal material of warm blooded animals.

The presence of faecal coliform bacteria in aquatic environments indicates that the water has been contaminated with the fecal material of man or other animals, i.e., the water resource may have been contaminated by pathogens or disease-producing bacteria or viruses which can also exist in fecal material. Worth mentioning, the consequences of waterborne bacteria and virus infection is polio, cholera, diarrhea, stomach cramps, typhoid fever, viral, and bacterial gastroenteritis and hepatitis A.

It is found that, the bacteria type (faecal coliform bacteria) in the drains and springs water samples was the same with that type in the selected Miocene groundwater samples. This observation proved that there is a direct connection between both the drains and springs, and the Miocene groundwater. This is also consistent with the hydrochemical data that show a high degree of similarity between the drains and springs and the Miocene groundwater.

The high infiltration coefficients of the surface soils, and the strong vertical permeability of the unsaturated section, facilitate the transfer of bacteria towards the Miocene aquifer. In addition, this may be due to the bio-films constituted on the walls of the karstic network (Dussart et al., 2003; DussartBaptista et al., 2003; Whiteley et al., 2001). These bacterial films or bio-films have a very specific behavior and can be released into the groundwater under random space-time conditions. 
Table 5: The microbiological analyses of selected surface water and groundwater samples in Siwa area

\begin{tabular}{|c|c|c|c|c|}
\hline $\begin{array}{l}\text { Sample } \\
\text { No. }\end{array}$ & Sample Name & $\begin{array}{l}\text { Total colony counts } \\
\left(\mathrm{cfu} / \mathrm{ml} \text { at } 37^{\circ} \mathrm{C}\right)\end{array}$ & $\begin{array}{l}\text { Total coliform counts } \\
\text { (M.P.N/100ml) }\end{array}$ & TSI \\
\hline \multicolumn{5}{|c|}{ Surface water } \\
\hline \multicolumn{5}{|c|}{ Lakes } \\
\hline 1 & El Maraki Lake & 105 & 0.00 & 0.00 \\
\hline 3 & Siwa Lake & 139 & 0.00 & 0.00 \\
\hline \multicolumn{5}{|c|}{ Drains } \\
\hline 4 & El Qarabeen El Omumy Drain & 123 & 27 & E.coli \\
\hline 5 & Omumy Drain & 191 & 40 & E.coli \\
\hline 6 & Gheet El Khalel Drain & 130 & 24 & E.coli \\
\hline 7 & Loeab Ali Arafa Drain & 135 & 67 & E.coli \\
\hline \multicolumn{5}{|c|}{ Springs } \\
\hline 8 & Ain Taghlia (Romani) & 140 & 30 & E.coli \\
\hline 9 & Ain Telwa & 120 & 20 & E.coli \\
\hline 10 & Ain Kharafala & 190 & 60 & E.coli \\
\hline 11 & Ain Korisht & 117 & 15 & E.coli \\
\hline 12 & Ain Abu Shrouf & 169 & 40 & E.coli \\
\hline 13 & Ain Fentas & 130 & 51 & E.coli \\
\hline \multicolumn{5}{|c|}{ Groundwater } \\
\hline \multicolumn{5}{|c|}{ Miocene aquifer } \\
\hline 15 & Sherif Senosy & 178 & 45 & E.coli \\
\hline 20 & Titkahamo Well & 165 & 0.00 & 0.00 \\
\hline 21 & Lotba Well & 195 & 22 & E.coli \\
\hline 22 & Nagdeen Well & 141 & 33 & E.coli \\
\hline 23 & Mohamed Omar Musa & 110 & 0.00 & 0.00 \\
\hline 24 & Abu Shrouf - EI Zeitoun Well & 132 & 40 & E.coli \\
\hline 25 & El Mortazaq Well & 154 & 52 & E.coli \\
\hline 26 & Siwa Well 1 & 240 & 0.00 & E.coli \\
\hline 27 & Siwa Well 2 & 90 & 0.00 & 0.00 \\
\hline 29 & Tekzerty Well 1 & 77 & 38 & E.coli \\
\hline 30 & Tegzerty Well 2 & 112 & 12 & E.coli \\
\hline 31 & EI Shaheim Well & 128 & 21 & E.coli \\
\hline 32 & El Moulok Well & 180 & 7 & E.coli \\
\hline 33 & $\begin{array}{l}\text { Abu El Makarim Al Ansary } \\
\text { Well }\end{array}$ & 96 & 0.00 & 0.00 \\
\hline \multicolumn{5}{|c|}{ Nubian sandstone aquifer } \\
\hline 34 & EI Dakror Well & 204 & 15 & E.coli \\
\hline 36 & El Ghazalat Well & 84 & 0.00 & 0.00 \\
\hline 37 & Korisht Well & 196 & 40 & E.coli \\
\hline Permiss & limits for drinking purposes & $\begin{array}{l}1.0 \times 10^{2} \mathrm{cfu} / \mathrm{ml} \\
\text { (Okonko et al., 2008) }\end{array}$ & $\begin{array}{l}\text { 2M.P.N./100ml } \\
(\text { FAO, 1997) }\end{array}$ & ------ \\
\hline
\end{tabular}

The karst aquifer includes valuable water resources, which sometimes are difficult to exploit and are always vulnerable to contamination, due to the specific hydrogeologic properties (International Association of Hydrogeology; IAH, 2009). Therefore, the fractured limestone aquifer (Miocene aquifer) requires increased protection and application of hydrogeologic methods for its investigation to avoid any contamination (Yousif et al., 2015). The spatial distributions of the polluted drains along with the polluted samples from different aquifers (Figs. 12 and 13) show that the structural lineaments (faults and/or joints) can play an important role as a conduit between the pollution source (drains) and the Miocene groundwater. One fault with its shear zone is observed with NW-SE trend passes across all drains (samples Nos. 4, 5, 6 and 7) and mediates the groundwater wells and springs. This fault is associated with a set of lineaments shows NE-SW trend. Also, the elevation map (DEM) shows that the most of wells and springs are falling in the low elevation areas which make them more likely to receive pollutants. Noteworthy, the presence of these lineaments plays an important role in the existence of the springs of Siwa Oasis and also in the hydraulic connection between the different aquifers. 


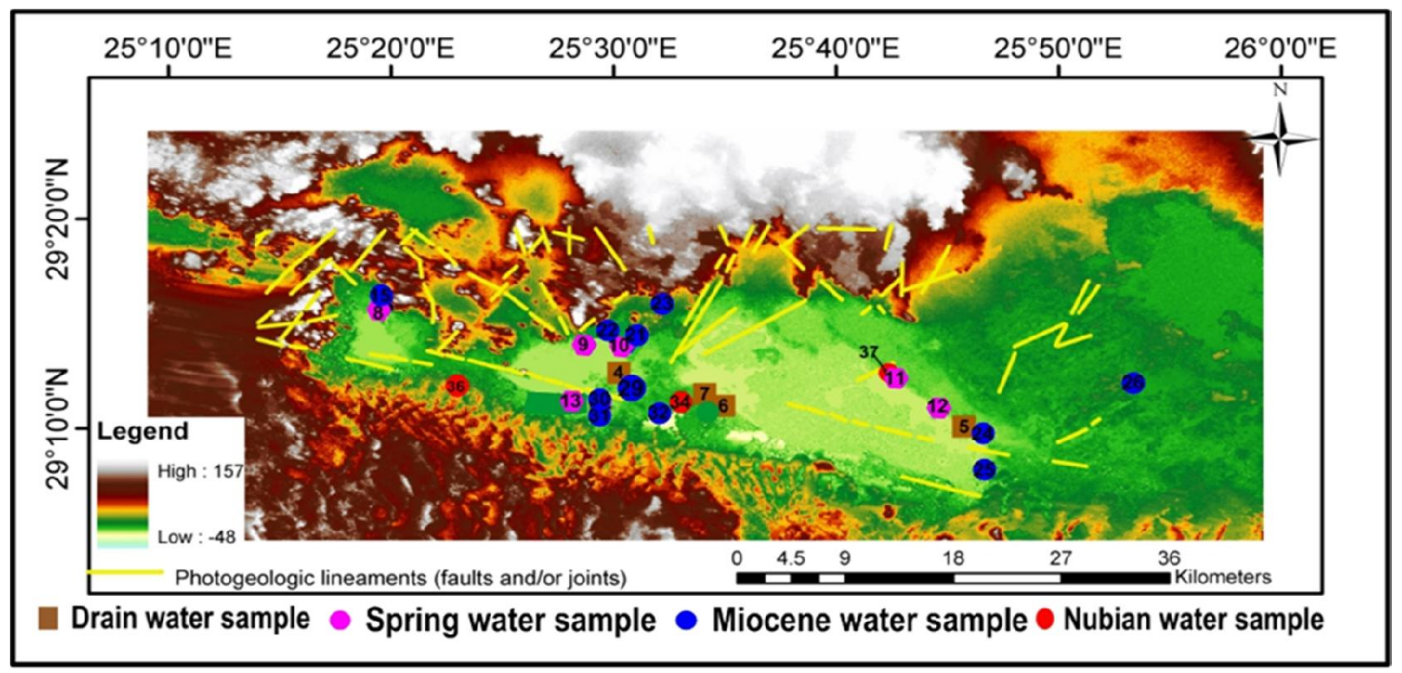

Fig.12: The structural lineaments (faults and/or joints) map

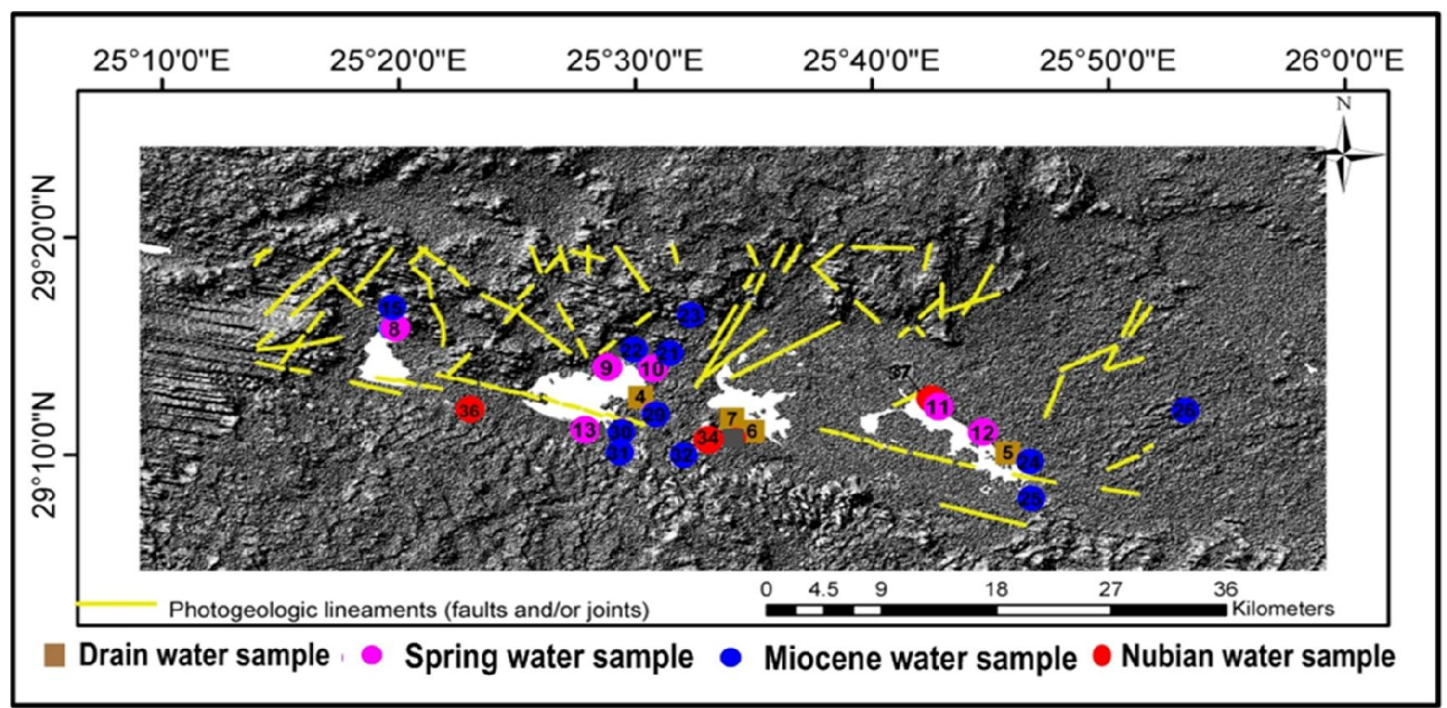

Fig.13: The hill shaded relief map

It is noticed that some Nubia sandstone groundwater wells (samples Nos. 34 and 37) were bacteriologically polluted as they located beside drain No.7 and spring No.11, respectively. This can be confirmed by the emission of the hydrogen sulfide gas from these wells which indicate that these wells were polluted, and this can be explained as follows; it is sometimes noticed that a foul smell is emitted from some Nubia sandstone groundwater wells, like the smell of rotten eggs, and that the reason for this smell is due to the emission of hydrogen sulfide gas from the well water. This is due to the presence of certain types of bacteria that use iron and manganese as part of their food or the presence of sulfurreducing bacteria that are naturally present and thrive in the low oxygen environments present in groundwater wells and utilize sulfur in water in the decomposition of rocks, soil and plants and use it as a source of energy and the result of this generation process is hydrogen sulfide gas as a by-product. Also, the hydrogen sulfide gas can be produced due to pollution of groundwater with untreated wastewater contaminants as a result of the presence of seepage from the sewage water.

This can be emphasized by both El Gammal (2015) and Salman et al. (2018), where the former stated that, in the recent decades, the agriculture sewage water covered most of Siwa depression forming salt-lakes and encroachment destroying the cultivated land widespread in the depression, which leads to disaster of geo-environmental problem in both the food and economic delineating the human activities and the landscape ravine. So, it must be rescued Siwa from sinking under agriculture sewage 
waters for long life. Hence, deliverance the continental Nubia sandstone water aquifer under Siwa from contamination by agriculture sewage and water table rise and deliverance the continental water (Nubia sandstone aquifer) under Siwa depression from mixing and contamination with agriculture sewage, while the other mentioned that the uncontrolled abstraction and unplanned expansion in the desert reclamation and application of agricultural fertilizers, pesticides and herbicides may adversely impact the Nubia sandstone aquifer quality.

In brief, the microbiological pollution of the Miocene groundwater (Upper aquifer) may be due to the seepage from the polluted drains and springs at certain depths through a fracture bedrock layer. This is because of both springs water (that contain human waste as a result of using them in showers as swimming pools) and the drains water (in which the uncontrolled sewage disposal of Siwa Oasis is dumped) was closed to the Miocene groundwater. So, the groundwater was contaminated due to the infiltration of the springs and drains water to it across the faults (Figs. 12 and 13). While in the Nubia sandstone groundwater (deep aquifer), the microbiological pollution may be due to the presence of some types of anaerobic microbial contamination that may be living in the aquifer where most of anaerobic microbes needs to make environmental adaptation to be able to live, i.e., the pollution of the Nubian sandstone aquifer is not man made factor (non human source).

\section{Statistical analyses (cluster analysis)}

The cluster analysis (CA) technique is used to classify the examined parameters of groundwater into categories or clusters based on their similarities or dissimilarities in the variation of the data sets using hierarchical cluster analysis (HCA). The degree of association between two objects is maximal if they belong to the same group and minimal otherwise. In hierarchical cluster analysis, the distance between samples is used as a measure of similarity (Vega et al., 1998). One of the main purposes of cluster analysis in the study area is to identify the Miocene groundwater samples that affected by seepage from the polluted drains and springs water system. The results of the cluster analysis (Dendogram) for the samples are represented in figure No.14. The CA grouped 27 sampling locations into 4 clusters named as 1,2,3 and 4. Clusters of the samples are listed in table (6), which indicates that each cluster has a water quality of its own, which is different from the other clusters.

Table 6: Cluster groups and their members of the surface water and groundwater samples in the study area

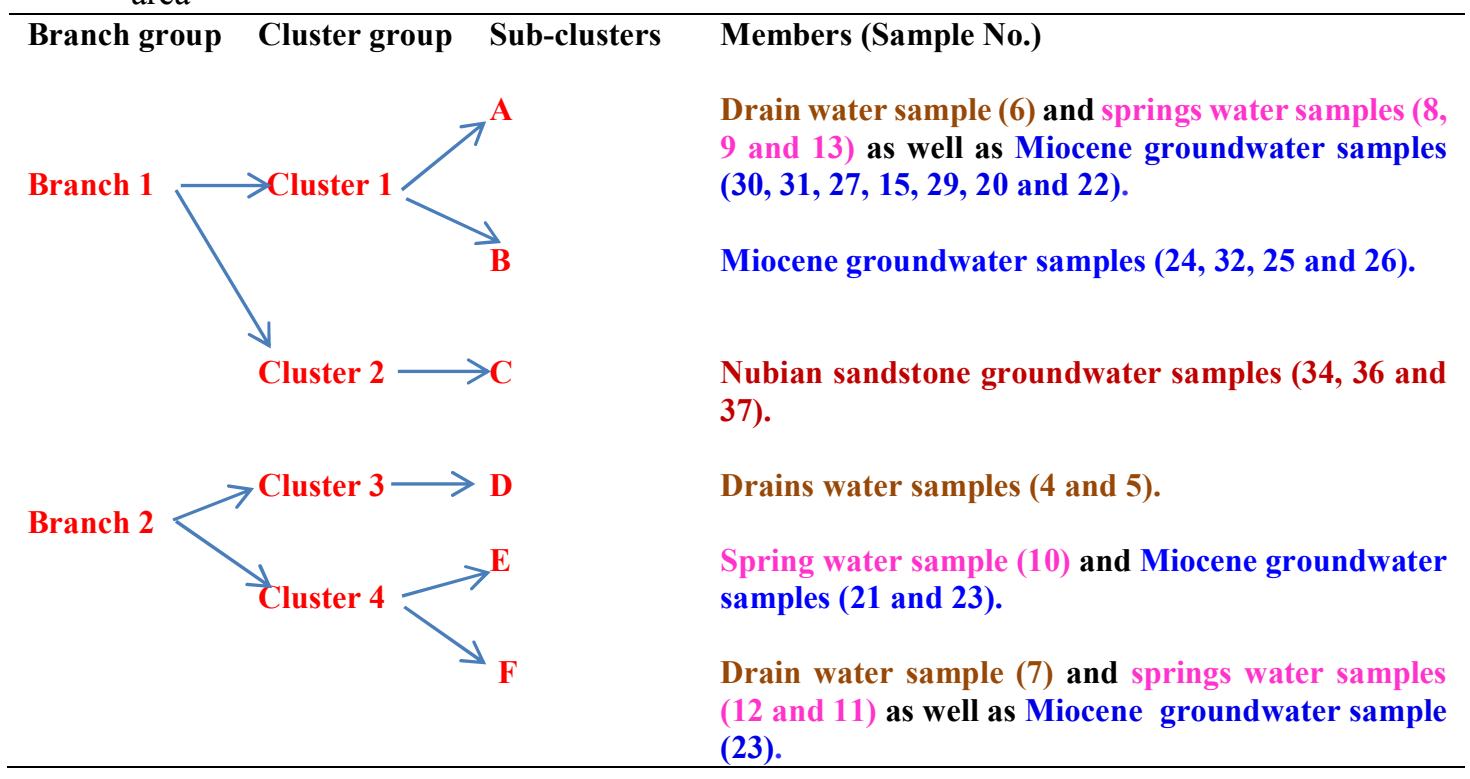




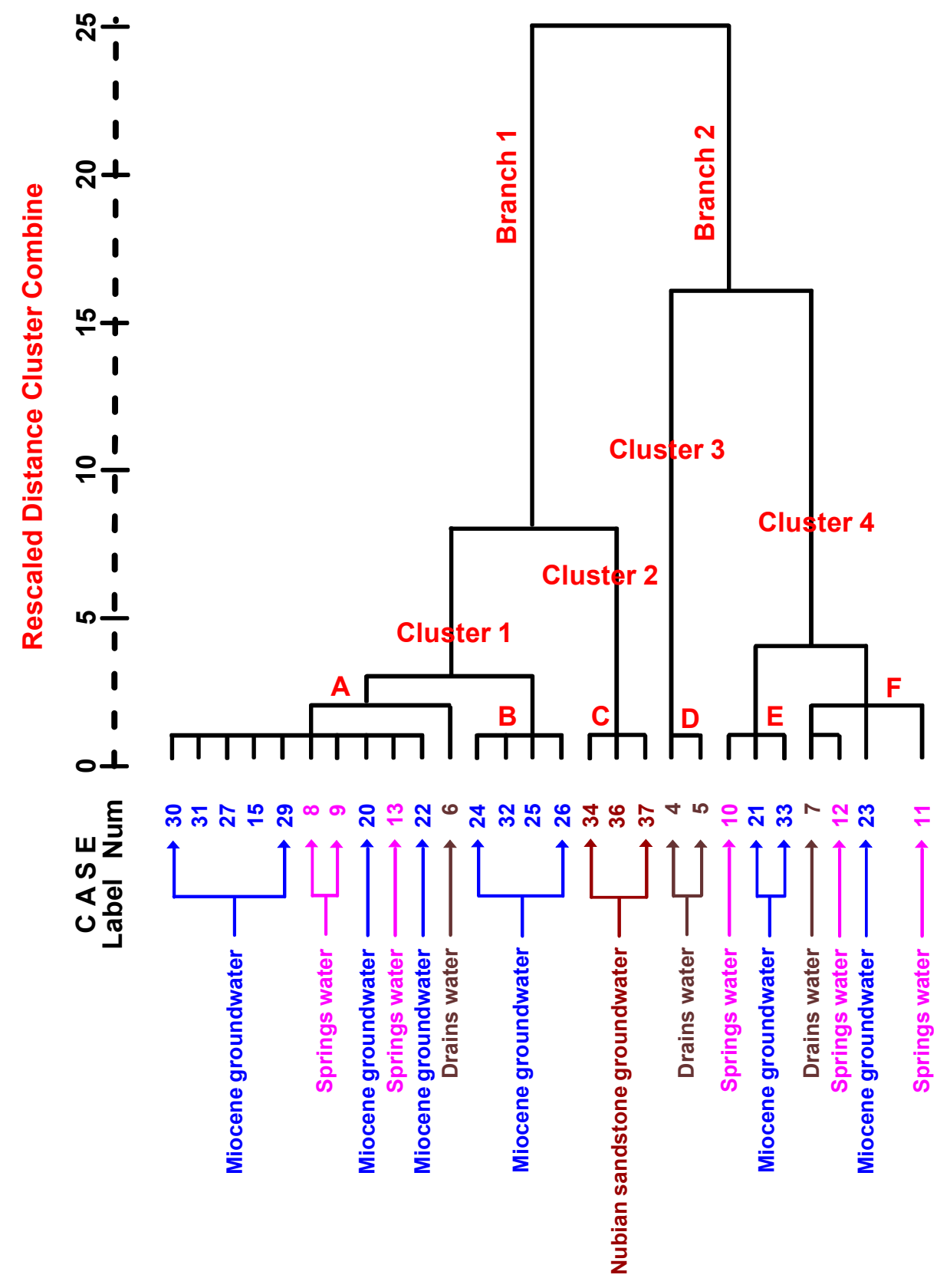

Fig.14: Dendogram of cluster analysis of both surface water and groundwater in the study area

Cluster No.1 is represented by 11 groundwater samples tapping the Miocene aquifer and four surface water samples representing both the drains and springs systems (Table 6). This cluster is subdivided into two sub-clusters (A and B) that contain 7 and 4 groundwater samples, respectively (Table 6). The groundwater samples in this cluster are distributed all over the study area. They are characterized by salinities varying between fresh water $(1091 \mathrm{mg} / \mathrm{l})$ and brackish water $(3191 \mathrm{mg} / \mathrm{l})$. The presence of drains and springs water samples between the groundwater samples in this cluster means that, the groundwater were affected by seepage from these drains and springs. 
Cluster No.2 (C) is represented by three groundwater samples tapping the Nubian sandstone aquifer (Table 6). The presence of this cluster within branch No.1 but separated than cluster No.1 (A and B) as in Fig.14, confirmed that the Nubian sandstone groundwater is not affected by the surface water (drains and springs water) in addition to that, the Miocene groundwater is recharged from the Nubian sandstone aquifer.

Clusters Nos.( $3 \& 4)$ are represented by six surface water samples (three water samples from both drains and springs water system) in addition to three groundwater samples tapping the Miocene aquifer (Table 6). They contain three sub-clusters (D, E and F). The groundwater samples in this cluster are located to the north and east of the study area and they are characterized by higher salinities than the previous clusters, where the salinity is varying between 3888 to $4965 \mathrm{mg} / \mathrm{l}$. This is attributed to the dissolution process of carbonate rocks during the subsurface flow of groundwater through cracks and joints in the study area. Noteworthy, the presence of the drains water samples Nos.(4 \& 5) in separated cluster No.3 (D) than the cluster No.4 (E and F) within the same branch No.2 means that the concerned Miocene groundwater $(21,23 \& 33)$ in the study area is affected only by the drain water sample No.7 and the springs water samples Nos.10, 11 and 12 and not affected by the drains Nos. $4 \& 5$.

The statistical analyses confirm that there is a hydraulic connection between the Nubian sandstone and Miocene aquifers in the study area. Also, some of the Miocene groundwater samples in the study area are bacteriologically polluted as they are affected by seepage from the surface water system (drains and springs water).

\section{Water Quality Evaluation}

Water of good drinking quality is of basic importance to human physiology and man's continued existence depends very much on its availability (Lamikanra, 1999 and FAO, 1997). Variation of groundwater quality in an area is a function of physical and chemical parameters that are greatly influenced by geological formations and anthropogenic activities (Belkhiri et al., 2010).

Chemically, the majority of the Miocene groundwater in the study area is unsuitable for drinking purposes as they have salinities as well as $\mathrm{Mn}, \mathrm{Fe}$ and $\mathrm{Zn}$ more than the permissible limits for drinking $1000,0.4,0.3$ and $0.05 \mathrm{mg} / 1$, respectively (WHO, 2011). Also bacteriologically, the majority of the Miocene groundwater in the study area is unsuitable for drinking purposes as they contaminated by total faecal coliform (Escherichia coli.). So, in brief, the majority of groundwater in the study area is unsuitable for drinking under ordinary conditions.

\section{Conclusion}

Water resources in Egypt are becoming scarce, where surface water resources originating from the Nile are now fully exploited. So, Egypt will be facing increasing water needs, demanded by a rapidly growing population, by increased urbanizations, by higher standards of living and by an agricultural policy which emphasizes expanded production in order to feed the growing population. For that, the supposed ideal solution for this problem is the use of the groundwater resources instead of the surface water (Nile water) especially at the desert areas. Where, the people in the Egyptian western desert are depending on groundwater as a source for drinking water, on the other hand, this groundwater needs more studies regarding its quality and sustainability.

This study has thrown light on both the geological, hydrochemical and the microbiological regime of Siwa Oasis as well as on the quality of the groundwater in Siwa Oasis which can be subjected to domestic and agricultural pollution in Siwa Oasis. So, thirty seven water samples were analyzed for several parameters $\left(\mathrm{pH}\right.$, electrical conductivity, temperature, $\mathrm{Ca}^{2+}, \mathrm{Mg}^{2+}, \mathrm{Na}^{+}, \mathrm{K}^{+}, \mathrm{CO}_{3}{ }^{2-}, \mathrm{HCO}_{3}{ }^{-}, \mathrm{SO}_{4}{ }^{2-}$ $, \mathrm{Cl}^{-}, \mathrm{NO}_{3}{ }^{-}, \mathrm{PO}_{4}{ }^{3-}, \mathrm{Fe}, \mathrm{Mn}$ and $\mathrm{Zn}$ in addition to bacteriological analysis.

The Miocene groundwater represents one of the main principal groundwater systems in Siwa oasis which are most heavily threatened by pollution. Where, agricultural developments and human activities as well as rapid urban growth contribute to the pollution of the groundwater and have markedly altered groundwater quality. Where, $60 \%$ of the studied groundwater samples have trace element concentrations more than the acceptable levels for drinking, the iron and manganese concentrations were considered the highest heavy metals concentrations at some studied groundwater samples. Also, the hydrochemical analyses show that, the majority of water samples have concentrations of nitrate and phosphate ions do not meet the water quality standards. Noteworthy, the bacteriological analyses show that bacteria concentrations meet water quality standards in several of the selected groundwater samples 
(71\%) and this contamination reflects the impacts of agricultural activities and human activities (untreated domestic wastewaters) on the groundwater quality and the strong intrinsic vulnerability of the aquifer.

\section{Recommendations}

1- Periodical physico-chemical analysis of water at source must be carried out to determine its quality for drinking.

2- The microbiological pollution of the Nubian Sandstone groundwater must be studied in deep to determine the microbial species that cause pollution.

3- Water quality should be controlled in order to minimize acute problems of water related diseases, which are endemic to the health of human.

4- The original source of any drinking water is rich in aquatic microbes, some of which could be dangerous if they enter the human body. Accordingly, the treatment of water for drinking involves stages where microbes are removed or destroyed before the water gets into homes. After purifying the water is subjected to tests by bacteriologists to ensure the safety for human consumption.

\section{Preventing or stopping}

Future groundwater source protection strategies should focus on the reduction of polluting activities near the Miocene groundwater. Consequently, in order to avoid bacterial contamination, it is necessary to stop several activities and practices in the area, such as:

1-The construction of permeable traditional septic tanks.

2-The spreading of animal excrement in badly selected sites.

3-The use of organic fertilizers.

4-The removal of liquid wastes towards the topographic basement and domestic landfill on badly selected sites.

\section{References}

Abdel-Mogheeth S.M., 1996. Groundwater hazards in Siwa Oasis, Egypt: Proceedings of the UNESCO/NWRC/ACSAD Workshops on Wadi Hydrology and Groundwater Protection, Cairo, Egypt (3-6 June 1996), 113-118.

Abd El-Samie S.G., N. El-Arabi and M.A. Ahmed, 2006. Use of stable isotopes to study the flow mechanism of the groundwater from the Nubia sandstone aquifer to the overlying carbonate layers: Ann. Geol. Surv., XXVIII, 569-585.

Abdulaziz A.M. and A.M. Faid, 2015. Evaluation of the groundwater resource potential of Siwa Oasis using three-dimensional multilayer groundwater flow model, Mersa Matruh Governorate, Egypt. Arab J Geosci, 8: 659-675.

Abou El-Magd, I. and A. Faid, 2007. Hydrogeological and environmental studies on Siwa Oasis, Egypt Using GIS technique. Egypt. J. Soil Sci. 47: 435-450.

Afifi A.H., 2005. Assessment of the hydrogeological conditions of groundwater in Siwa Oasis, North Western Desert, Ph.D. Thesis, Minufiya Univ., Egypt, 98.

Aggour T.A. and A.M. Faid, 2006. Hydrogeology of Siwa Oasis And Landuse Map, Egypt J. Remote Sensing \& SpaceSci. 9: 135 - 156 .

Aly A.A., 2001. Spatiotemporal monitoring and assessment of water resources in Siwa Oasis. M.Sc Thesis, Fac. of Agric., Alex. Univ., Egypt.

Aly A.A., 2007. A holistic ecosystem approach for sustainable management of land and water resources in Siwa Oasis. Ph.D. Thesis, Faculty of Agriculture, Alexandria University, Egypt.

Aly A.A., H.M. Gaber and F.M. Kishk, 2008. Long term change detection and assessment of groundwater quality in Siwa Oasis, Egypt available water resources and future constrain conference, hold on the geography and GIS Dept., Faculty of Arts, Alexandria University, Alexandria, Egypt, 19.

Aly A.A., A.A. Abbas and L. Benaabidate, 2011. Hydrochemistry and quality of groundwater resources in Egypt: case study of the Egyptian southern oases. Chapter 17, in water security in the Mediterranean region, NATO security through science series C: Environmental Security. Springer, Netherlands, 239-254. 
Aly A.A., A.M. Al-Omran and M.M. Alharbya, 2014a. The water quality index and hydrochemical characterization of groundwater resources in Hafar Albatin, Saudi Arabia. Arab J Geosci. doi:10.1007/s12517-014-1463-2

Aly A.A., 2015. Hydrochemical characteristics of Egypt western desert oases groundwater. Arab J Geosci., 8: 7551-7564.

Aly A.A., F.M. Kishk, H.M. Gaber and A.M. Al-Omran, 2016. Long-term detection and hydrochemistry of groundwater resources in Egypt: Case study of Siwa Oasis. Journal of the Saudi Society of Agricultural Sciences, 15: 67-74.

American Society for Testing and Materials (ASTM), 2002. Water and environmental technology. Annual book of ASTM standards, Sec.11, Vols.11.01 and 11.02, West Conshohocken, U.S.A.

American Public Health Association (APHA), 1998. Standards methods for the examination of water and wastewater. $20^{\text {th }}$ ed., New York, U.S.A.

Belkhiri L., A. Boudoukha, L. Mouni and T. Baouz, 2010. Application of multivariate statistical methods and inverse geochemical modeling for characterization of groundwater - a case study: Ain Azel Plain (Algeria). Geoderma, 159: 390-398.

Burkart M.R. and D.W. Kolpin, 1993. Hydrologic and land use factors associated with herbicides and nitrates in near-surface aquifers. J. Environ. Qual., 22: 646-656.

Chebotarev I.I., 1955. Metamorphism of natural waters in the crust of weathering. Geochim. Cosmochim. Acta, 8: 22-212.

Conoco, 1987. Geological map of Egypt, NH35 SW, Egyptian General Petroleum Corporation (EGPC), Egypt.

Dahab K.A., 2004. Impact of the present groundwater exploitation system on the Nubia sandstone aquifer in Siwa Oasis, Western Desert, Egypt. $6^{\text {th }}$ Intern. Conf. On Geochemistry. Alex Univ., Egypt, 319-337.

Deep Groundwater Working Group/Environmental Policy and Institutional Strengthening Indefinite Quantity Contract (DGWG/EPIQ), 1998. Hydrogeology of deep aquifers in the Western Desert and Sinai: Ministry of Public Works of Egypt, Report No.10, APRP - Water Policy Reform Activity Contract peE-I-00-96-00002-00, Task Order 807: 197.

Dussart L., J.P. Dupont, I. Zimmerlin, M. Lacroix, J.M. Saiter, G.A. Junter and T. Jouenne, 2003. Occurrence of sessile pseudomonas orysihabitans from a karstified chalk aquifer. Water Research 37(7): 1593-1600.

Dussart-Baptista L., N. Massei, J.P. Dupont and T. Jouenne, 2003. Transfer of bacteria-contaminated particles in a karst aquifer: evolution of contaminated materials from a sinkhole to a spring. J. Hydrol. 284: 285-295.

Eckhardt D.A.V. and P.E. Stackelberg, 1995. Relation of groundwater quality to land use on Long Island, NewYork. Groundwater 33:1019-1033.

Edema M.O, A.M. Omemu and O.M. Fapetu, 2001. Microbiology and Physicochemical Analysis of different sources of drinking water in Abeokuta. Nigeria. Niger. J. Microbiol. 15(1): 57-61.

Egyptian General Petroleum Corporation (EGPC), 1992. Western Desert, oil and gas fields (a comprehensive overview). Cairo, 431.

El Hossary M.F., 1999. Evaluation and management of groundwater resources in Siwa area with emphasis on the Nubian Sandstone aquifer. Ph.D. Thesis, Fac. Sci. Ain Shams Univ., 143.

El Hossary M.F., 2013. Investigating the development challenges to Siwa Oasis, Northwestern Desert, Egypt: New York Science Journal, 6(4): 55-61.

El Gammal E.A., 2015. On people narrow with agriculture sewage water in closed oases in arid environment, Siwa Oasis, Egypt as a case study. Merit Res. J. Agric. Sci. Soil Sci., ISSN: 23502274, 3(5): 070-081.

El-Gindy A.R. and M.A. El-Askary, 1969. Stratigraphy structure and origin of Siwa depression, Western Desert of Egypt. Bulletin of the American Association of petroleum Geologists, 53: 603625 .

El-Sayed S.A., Kh.A. Allam, M.H. Salama and H. El Begawy, 2017. Investigation of Chemical and radiochemical fingerprints of water resources in Siwa Oasis, Western Desert, Egypt. Arab Journal of Nuclear Science and Applications, 50(1): 158-178.

El-Shazly E.M. and M.A. Abdel Hady, 1976. Geological interpretation of Landsat Images of the Qattara Depression Area. Remote Sensing Center, Academy of Science, Cairo. 
El-Shazly M.M. and S.M. Abdel-Mogheeth, 1991. Remarks on the water resources and the potential of horizontal agricultural expansion in Siwa Oasis. $1^{\text {st }}$ workshop on rehabilitation and development of Siwa oasis (26-29 November 1991), Mersa Matruh, Egypt.

Ezzat M.A., 1974. Groundwater series in the Arab Republic of Egypt, exploitation of groundwater in the El-Wadi E1-Gedid project area, parts I-IV. General Desert Development Authority, Ministry of Irrigation, Cairo.

Fapetu O.M., 2000. Comparative Analysis of Different Sources of Drinking Water in Abeokuta South L.GA., Ogun State (B.Sc. Thesis) UNAAB Abeokuta, 44.

Farrag A.A. and U.R. Sediek, 2017. Evaluation hydrochemical analyses of groundwater and its suitability for drinking and agricultural uses at Western Desert of Egypt. Twentieth International Water Technology Conference, IWTC20, Hurghada, 18-20.

Fishman M.J. and L.C. Friedman, 1985. Methods for determination of inorganic substances in water and fluvial sediments. U.S. Geol. Surv. Book 5, Chapter A1. Open File Report, 85-495, Denver, Colorado, U.S.A.

Food and Agriculture Organization (FAO), 1997. Chemical analysis manual for food and water. $5^{\text {th }}$ ed., FAO, Roma, Italy 1: 20-26.

General Petroleum Company (GPC), 1991. Salinity study on Pre-Upper Cenomanian (PUC) sediments in Siwa area. Internal technical report in the General Petroleum Company, Nasr City, Cairo

Hedia R.M.R., 2015. Assessment of drainage water quality in Siwa Oasis and its suitability for reuse in agricultural irrigation. Egypt. J. Soil. Sci., 55 (4): 501-515.

Ibrahim S.A., 1991. Studies on groundwater possibilities in the northern part of the Western DesertEgypt: Ph.D. Thesis, Cairo Univ., Cairo, Egypt, 292.

Ihekoronye A.I. and P.O. Ngoddy, 1985. Integrated Food Sciences and Technology for the Tropics. Macmillan Press, London, Oxford, 95-195.

International Association of Hydrogeology (IAH), (2009). Karst Aquifer http://www.iah.org/karst/karst_hydrogeology.html. Accessed 15 March 2014.

Kalkan Ç., K. Yapsakli, B. Mertoglu, D. Tufan and A. Saatci, 2011. Evaluation of biological activated carbon (BAC) process in wastewater treatment secondary effluent for reclamation purposes. Desalination J., 265(1-3): 266-273.

Kotoski J.E., 1997. Spring Harbor Environmental Magnet Middle School.

Kumar M., A.L. Ramanathan, M.S. Rao and B. Kumar, 2006. Identification and evaluation of hydrogeochemical processes in the groundwater environment of Delhi, India. J Environ Geol 50:1025-1039.

Lamikanra A., 1999. Essential microbiology for students and practitioner of pharmacy, medicine and microbiology, $2^{\text {nd }}$ ed. Amkra books Lagos, 406.

Lukhele L.P., R. Krause, B. Mamba and M. Momba, 2010. Synthesis of silver impregnated carbon nanotubes and cyclodextrin polyurethanes for the disinfection of water. Water Research Commission 36(4): 4.

Mengnjo J.W., O. Takeshi, Y.F. Wilson, N.A. Samuel, Y.S. Justice, E.A. AsoboNkengmatia , T. Gregory and V.H. Joseph, 2013. Hydrochemistry of shallow groundwater and surface water in the Ndop plain, North West Cameroon. African Journal of Environmental Science and Technology, 7(6): 518-530.

Mohammad M.R., K. Sediek, H. El-Sobky and M. El-Raey, 1999. Structural analysis and groundwater potentialities using TM Image and field investigations, case study: Siwa region, Western Desert, Egypt. In: Second International Symposium on Operationalization of Remote Sensing, ITC, Enschede, the Netherlands, 16-20.

Okonko I.O., A.O. Damilola, T.A. Ogunnusi, E.A. Fajobi and O.B. Shittu, 2008. Microbiological and physicochemical analysis of different water samples used for domestic purposes in Abeokuta and Ojota, Lagos State, Nigeria. Afr. J. Biotechnol., 7(5): 617-621.

Piper A.M., 1953. A graphic representation in the geochemical interpretation of groundwater analysis. American Geophysical Union Transactions, U.S.A., 25(105): 914 - 923.

Rainwater F.H. and L.L. Thatcher, 1960. Methods for collection and analysis of water samples. U.S. Geol. Surv. Water Supply. Paper No.1454, U.S.A., 301.

Research Institute for Groundwater (RIGW), 1996-1999. Project on development of Siwa Oasis, well inventory, 79. 
Research Institute for Groundwater (RIGW), 2012. Technical report for Siwa water points survey.

Richman M., 1997. Industrial water pollution. Wastewater, 5(2): 24-29.

Rizkalla I.R. and B.M. Awad, 1990. Modelling of the basement surface of Siwa-Qattara Depression area, northern western desert of Egypt. Qatar Univ Sci Bull 10:339-362.

Said R., 1962. Geology of Egypt. Elsevire Published Company, Amsterdam, New York, 377.

Saleh I.H., A.M. Elnaggar and H.Z. Ibrahim, 2016. Risk assessment of radionuclides in groundwater in Siwa Oasis, Egypt. International Journal of Advanced Research (IJAR), 4 (11): 1459-1466.

Salheen M.A., 2013. Towards a water based regional development model for Siwa oasis in the Western Desert-Egypt: GCCBS 2013 Conference Program.

Sallam E.S., A.K. Abd El-Aal, Y.A. Fedorov, O.R. Bobrysheva and D.A. Ruban, 2018. Geological heritage as a new kind of natural resource in the Siwa Oasis, Egypt: The first assessment, comparison to the Russian South, and sustainable development issues. J. Afr. Earth Sci., 144: 151160.

Salman S.A., E.M. Abu El Ella, E.M. Seleem and A.A. Elnazer, 2018. Groundwater quality and environmental investigations in Siwa Oasis, Egypt. International Journal of Recent Advances in Multidisciplinary Research, 5(7): 3951-3958.

Schakschouk A.M., 2002. Drainage water reuse to control water table in Siwa Oasis. Alex. Sci. Exch. 23, $121-156$.

Shata A.A., 1982. Hydrogeology of the great Nubia sandstone basin: Egypt, Geology Journal, London, V.15.

Siwa Information Center (SIC), 2019. Statement support centre and decision making, center and city of Siwa - Matruh Governorate, Egypt (In Arabic).

Sonntag C., U. Thorweihe, J. Rudolph, E.P. Lohnert, C. Junghans, K.O. Munnich, E. kliitzch, E.M. ElShazly and F.M. Swailem, 1980. Paleclimatic evidence in apparent C-14 ages of saharian groundwaters: Radiocarbon, 22(3): 871-878.

Tebutt T.H.Y., 1983. Principles of Quality Control. Pergamon, England, 235.

Vega M., R. Pardo, E. Barrado and L. Deban, 1998. Assessment of seasonal and polluting effects on the quality of river water by exploratory data analysis. Water Research, 32: 3581-3592.

Whiteley M., J.R. Ott, E.A. Weaver and R.J. McLean, 2001. Effects of community composition and growth rate of aquifer biofilm bacteria and their susceptibility to Betadine disinfection. Environ. Microbiol. 3(1): 43-52.

World Health Organization (WHO), 2011. Guideline for drinking water quality. $4^{\text {th }}$ ed. Geneva, 518 .

Yousif M., T. Oguchi, K. Anazawa and T. Ohba, 2015. Framework for Investigation of karst aquifer in an arid zone, using isotopes, remote sensing and GIS applications: the northwestern coast of Egypt. Environ. Process., 2(1): 37-60. DOI 10.1007/s40710-015-0063-9. 